\title{
Biomaterial-Assisted Regenerative Medicine
}

\author{
Teruki Nii $1,2, *$ (D) and Yoshiki Katayama $1,2,3,4,5, *$ \\ 1 Department of Applied Chemistry, Faculty of Engineering, Kyushu University, 744 Motooka, Nishi-ku, \\ Fukuoka 819-0395, Japan \\ 2 Graduate School of Systems Life Sciences, Kyushu University, 744 Motooka, Nishi-ku, \\ Fukuoka 819-0395, Japan \\ 3 Center for Future Chemistry, Kyushu University, 744 Motooka, Nishi-ku, Fukuoka 819-0395, Japan \\ 4 International Research Center for Molecular Systems, Kyushu University, 744 Motooka, Nishi-ku, \\ Fukuoka 819-0395, Japan \\ 5 Department of Biomedical Engineering, Chung Yuan Christian University, 200 Chung Pei Rd., \\ Chung Li 32023, Taiwan \\ * Correspondence: nii.teruki.204@m.kyushu-u.ac.jp (T.N.); katayama.yoshiki.958@m.kyushu-u.ac.jp (Y.K.)
}

Citation: Nii, T.; Katayama, Y. Biomaterial-Assisted Regenerative Medicine. Int. J. Mol. Sci. 2021, 22, 8657. https://doi.org/10.3390/ ijms22168657

Academic Editor: Agata Przekora

Received: 22 July 2021

Accepted: 10 August 2021

Published: 12 August 2021

Publisher's Note: MDPI stays neutral with regard to jurisdictional claims in published maps and institutional affiliations.

Copyright: (C) 2021 by the authors. Licensee MDPI, Basel, Switzerland. This article is an open access article distributed under the terms and conditions of the Creative Commons Attribution (CC BY) license (https:// creativecommons.org/licenses/by/ $4.0 /)$.

\begin{abstract}
This review aims to show case recent regenerative medicine based on biomaterial technologies. Regenerative medicine has arousing substantial interest throughout the world, with "The enhancement of cell activity" one of the essential concepts for the development of regenerative medicine. For example, drug research on drug screening is an important field of regenerative medicine, with the purpose of efficient evaluation of drug effects. It is crucial to enhance cell activity in the body for drug research because the difference in cell condition between in vitro and in vivo leads to a gap in drug evaluation. Biomaterial technology is essential for the further development of regenerative medicine because biomaterials effectively support cell culture or cell transplantation with high cell viability or activity. For example, biomaterial-based cell culture and drug screening could obtain information similar to preclinical or clinical studies. In the case of in vivo studies, biomaterials can assist cell activity, such as natural healing potential, leading to efficient tissue repair of damaged tissue. Therefore, regenerative medicine combined with biomaterials has been noted. For the research of biomaterial-based regenerative medicine, the research objective of regenerative medicine should link to the properties of the biomaterial used in the study. This review introduces regenerative medicine with biomaterial.
\end{abstract}

Keywords: regenerative medicine; biomaterials; cell transplantation; tissue engineering; drug research

\section{Introduction}

Regenerative medicine is one of the most attractive fields in recent biomedical engineering. For the development of regenerative medicine, it is essential to enhance cell activity. For example, in the damaged or injured tissues, the natural healing potential is too low for cells to migrate, proliferate, and differentiate. If damaged cells' natural healing potential can be enhanced by using scientific technology, "patient-friendly" tissue regeneration could be achieved. For in vitro research, living cells should be used with satisfying functions and viability [1]. Cells are usually cultured in a dish that is mainly composed of polystyrene-this culture condition is artificial, and the environmental situation is quite different from the original tissues. The difference in the cell condition leads to low cell activity compared to in vivo, as cells in the body interact well with other cells or extracellular matrix (ECM), resulting in enhanced cell activity in their differentiation [2], proliferation [3], metabolism [4], or cytokine secretion [5,6]. The drug effect found in vitro drug screening conditions is not always the same as in a preclinical or clinical study because of the difference in the cell condition or activity [7-9]. If the cells with high activity are used in drug screening, the efficient evaluation of drug effects could be achieved. Thus, for 
the advancement of regenerative medicine, it is essential to enhance the function or activity of cells both in vivo and in vitro (Figure 1).

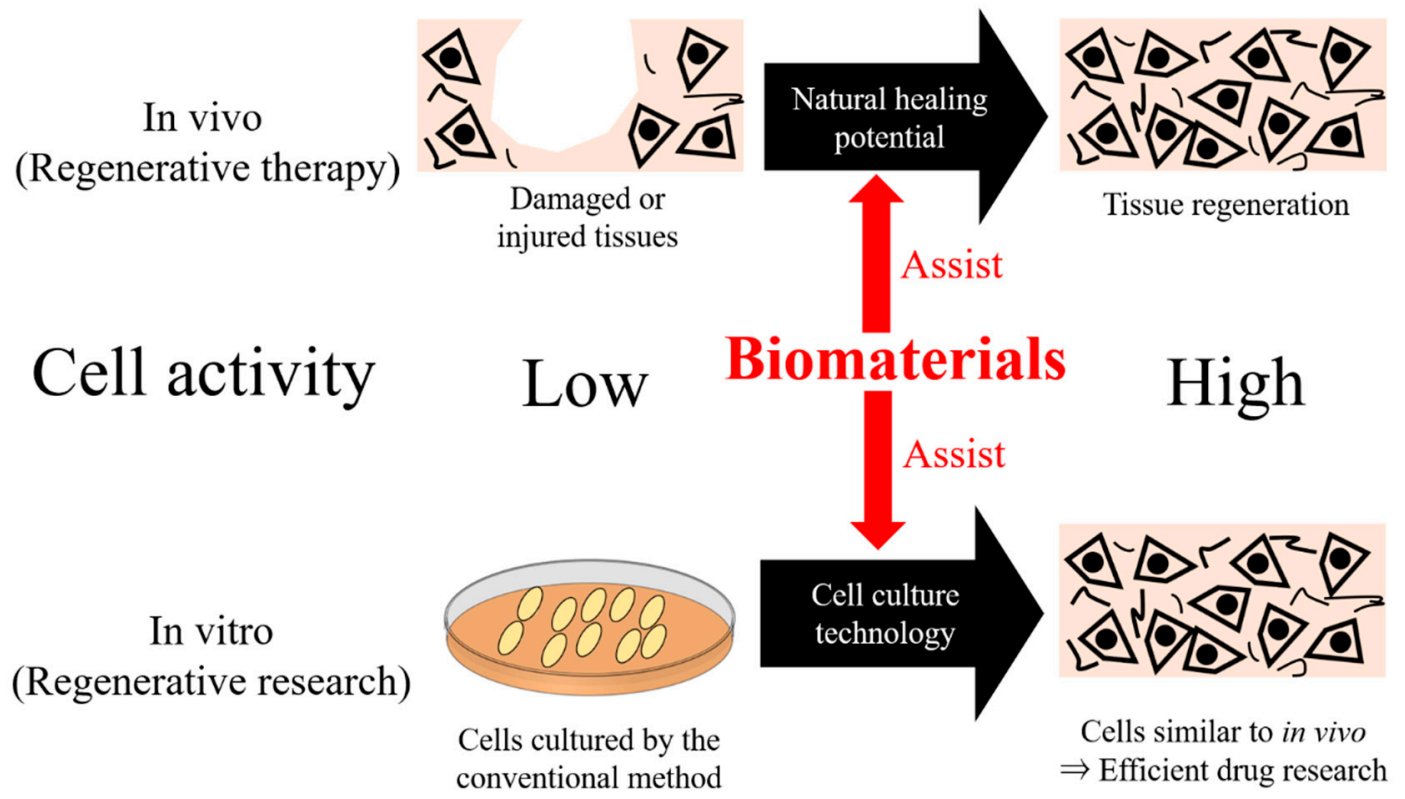

Figure 1. Biomaterials are promising methods to enhance the biological function of cells in vivo and in vitro, leading to the realization of regenerative medicine. In vivo, tissue regeneration can be achieved when the activity of cells in the damaged tissues enhances. Furthermore, if the cell activity is high enough in cell culture, similar to in vivo, it is possible to effectively predict the drug effect in a preclinical or clinical study. Thus, biomaterial-assisted regenerative medicine has been recently identified as a promising approach.

The use of biomaterials is one of the most effective methods to enhance cell activity (Figure 1). The American National Institute for Health (NIH) standard definition of biomaterials is "any substance or combination of substances, other than drugs, synthetic or natural in origin, which can be used for any period of time, which augments or replaces partially or totally any tissue, organ of function of the body, in order to maintain or improve the quality of life of the individual" [10]. In particular, biomaterials composed of ECM components can be useful to enhance cell activity [11,12], because it is well known that ECM enables cells to enhance viability or function [13-15].

Polymeric biomaterials, one of the essential biomaterials, can be classified into natural biomaterials and synthetic biomaterials. Natural biomaterials are composed of polysaccharides (chitosan, alginate, or hyaluronic acid) or peptide (collagen or gelatin), while polyethylene glycol, poly(lactic acid), or poly(lactic-co-glycolic acid) are well known synthetic polymers. The advantage of natural biomaterials is their high biocompatibility, as the endogenous enzymes can degrade the biomaterials. On the other hand, synthetic polymers have flexibility in their structural design to modify cell functions easily [12]. Therefore, it is essential to understand the properties of each biomaterial and select the appropriate biomaterials considering the purpose of the studies.

The objective of this review is to show recent regenerative medicine approaches based on biomaterial technologies, because it is essential to understand the properties of each biomaterial and select the appropriate biomaterial for each potential regenerative medicine. This review introduces recent representative studies of regenerative medicine, such as tissue engineering or drug research, using several biomaterials.

\section{Regenerative Medicine Combined with Biomaterials}

The basic information of several biomaterials and biomaterials-assisted regenerative medicine are introduced in Table 1, which summarizes recent regenerative medicine combined with biomaterials. We collected the studies including three keywords: research 
using representative biomaterials, research to show the result of enhancing biological function, and research reported in the last five years. As representative natural biomaterials, collagen, gelatin, alginate, chitosan, silk fibroin, agarose, and Matrigel were selected. In contrast, poly(lactic acid) and poly(lactic-co-glycolic acid) for synthetic biomaterials were introduced in this review. Although there are other synthetic polymers, the two polymers were selected because of the medical application, availability, and ease to handle.

Table 1. Recent reports on regenerative medicine combined with biomaterials.

\begin{tabular}{|c|c|c|c|c|c|}
\hline Biomaterials & Ref. & Date & $\begin{array}{l}\text { Tissue } \\
\text { Targeted }\end{array}$ & $\begin{array}{l}\text { In Vitro (Cell Type)/In Vivo } \\
\text { (Animal Type) Testing }\end{array}$ & Results Featured \\
\hline \multirow[t]{8}{*}{ Collagen } & [16] & 2018 & Bone & $\begin{array}{l}\text { In vitro (human mesenchymal } \\
\text { stem cells (MSC))/In vivo } \\
\text { (mouse) }\end{array}$ & $\begin{array}{l}\text { The scaffold of collagen and biphasic calcium } \\
\text { phosphate nanoparticles with a controlled } \\
\text { release of dexamethasone enabled the } \\
\text { enhancement of osteogenesis from human } \\
\text { MSC. In addition, bone regeneration was } \\
\text { observed in nude mice. }\end{array}$ \\
\hline & [17] & 2019 & Bone & $\begin{array}{l}\text { In vitro (human MSC and } \\
\text { human umbilical vein } \\
\text { endothelial cells) }\end{array}$ & $\begin{array}{l}\text { MSC and umbilical vein endothelial cells } \\
\text { multicellular spheroids encapsulated in } \\
\text { collagen/fibrin hydrogel showed efficient } \\
\text { osteogenic differentiation. }\end{array}$ \\
\hline & [18] & 2020 & Cartilage & $\begin{array}{l}\text { In vitro (rabbit } \\
\text { chondrocytes)/In vivo } \\
\text { (mouse) }\end{array}$ & $\begin{array}{l}\text { Porous fish collagen scaffolds promoted } \\
\text { cartilage formation in vitro and in vivo. }\end{array}$ \\
\hline & [19] & 2017 & Muscle & $\begin{array}{l}\text { In vitro (rat skeletal } \\
\text { myoblasts) }\end{array}$ & $\begin{array}{l}\text { The 3D microgroove collagen scaffolds } \\
\text { triggered cell assembly into anisotropic } \\
\text { muscle bundles. }\end{array}$ \\
\hline & [20] & 2017 & Cancer & $\begin{array}{l}\text { In vitro (human breast } \\
\text { cancer cells) }\end{array}$ & $\begin{array}{l}\text { Anisotropic scaffolds supported the migration } \\
\text { of invasive cancer cells. }\end{array}$ \\
\hline & [21] & 2018 & Cancer & $\begin{array}{l}\text { In vitro (human breast cancer } \\
\text { cells and fibroblasts) }\end{array}$ & $\begin{array}{l}\text { Tool of cancer cells and collagen gels } \\
\text { containing fibroblasts combination system } \\
\text { enabled the evaluation of desmoplasia, cancer } \\
\text { proliferation, or invasion. }\end{array}$ \\
\hline & [22] & 2019 & Cancer & $\begin{array}{l}\text { In vitro (human pancreatic } \\
\text { cancer cells, human lung } \\
\text { cancer cells, and fibroblasts) }\end{array}$ & $\begin{array}{l}\text { Cancer cells attached and migrated on the } \\
\text { collagen matrix containing fibroblasts. }\end{array}$ \\
\hline & [23] & 2019 & Cancer & $\begin{array}{l}\text { In vitro (human breast } \\
\text { cancer cells) }\end{array}$ & $\begin{array}{l}\text { Collagen matrices with fibril bending stiffness } \\
\text { indicated the spreading and clustering of } \\
\text { invasive cancer cells. }\end{array}$ \\
\hline \multirow[t]{5}{*}{ Gelatin } & [24] & 2015 & Cardiac & $\begin{array}{l}\text { In vitro (human } \\
\text { cardiovascular cell derived } \\
\text { from iPS cells) } / \text { In vivo } \\
\text { (mouse) }\end{array}$ & $\begin{array}{l}\text { Multilayered thick cell sheets were viable by } \\
\text { stacked with gelatin gels between each } \\
\text { cell sheet. }\end{array}$ \\
\hline & [25] & 2018 & Cardiac & In vivo (rat) & $\begin{array}{l}\text { Basic fibroblast growth factor release from } \\
\text { gelatin gels enabled the cell sheets to improve } \\
\text { cardiac contractile function. }\end{array}$ \\
\hline & [26] & 2017 & Epithelial & $\begin{array}{l}\text { In vitro (mouse mammary } \\
\text { epithelial cells and mouse } \\
\text { preadipocyte cells) }\end{array}$ & $\begin{array}{l}\text { Epithelial and preadipocyte spheroids } \\
\text { incorporating gelatin gels promoted the } \\
\text { expression level of laminin. }\end{array}$ \\
\hline & [27] & 2017 & Epithelial & $\begin{array}{l}\text { In vitro (mouse mammary } \\
\text { epithelial cells) }\end{array}$ & $\begin{array}{l}\beta \text {-casein expression was high for epithelial } \\
\text { spheroids incorporating gelatin gels. }\end{array}$ \\
\hline & [28] & 2018 & Pancreas & In vitro (rat insulinoma cells) & $\begin{array}{l}\text { The incorporation of gelatin gels into } \\
\text { insulinoma spheroids enabled } \\
\text { insulin secretion. }\end{array}$ \\
\hline
\end{tabular}


Table 1. Cont.

\begin{tabular}{|c|c|c|c|c|c|}
\hline Biomaterials & Ref. & Date & $\begin{array}{l}\text { Tissue } \\
\text { Targeted }\end{array}$ & $\begin{array}{l}\text { In Vitro (Cell Type)/In Vivo } \\
\text { (Animal Type) Testing }\end{array}$ & Results Featured \\
\hline & [29] & 2018 & Ovarian & In vivo (mouse) & $\begin{array}{l}\text { The transplantation of gelatin sheets capable of } \\
\text { basic fibroblast growth factor with ovarian } \\
\text { tissues significantly increased the proliferation } \\
\text { of stromal and endothelial cells. }\end{array}$ \\
\hline & {$[30]$} & 2019 & $\begin{array}{l}\text { Wound } \\
\text { healing }\end{array}$ & In vivo (mouse) & $\begin{array}{c}\text { Gelatin sheets impregnated platelet-rich } \\
\text { plasma accelerated the capillary and } \\
\text { tissue formation. }\end{array}$ \\
\hline & {$[31]$} & 2019 & Cancer & $\begin{array}{l}\text { In vitro (human lung cancer } \\
\text { cells and fibroblasts) }\end{array}$ & $\begin{array}{c}\text { A co-culture tool of cancer cells and fibroblast } \\
\text { spheroids incorporating gelatin gels containing } \\
\text { a p53 inhibitor can evaluate the invasion level } \\
\text { of cancer cells. }\end{array}$ \\
\hline & {$[6]$} & 2020 & Cancer & $\begin{array}{l}\text { In vitro (human lung cancer } \\
\text { cells and fibroblasts) }\end{array}$ & $\begin{array}{c}\text { The fibroblasts spheroids incorporating gelatin } \\
\text { gels capable of transforming growth factor- } \beta 1 \\
\text { increased the invasion rate of cancer cells } \\
\text { similar to in vivo. }\end{array}$ \\
\hline & [32] & 2020 & Cancer & $\begin{array}{l}\text { In vitro (human lung, breast, } \\
\text { and hepatic cancer cells, } \\
\text { fibroblasts, and macrophages) }\end{array}$ & $\begin{array}{l}\text { The gelatin gel-based drug release system was } \\
\text { able to mimic the invasion ability of cancer } \\
\text { cells, responding to the tissue region. }\end{array}$ \\
\hline \multirow[t]{9}{*}{ Alginate } & [33] & 2017 & Germ cells & $\begin{array}{l}\text { In vitro (mouse embryonic } \\
\text { stem cells) }\end{array}$ & $\begin{array}{l}\text { Alginate-collagen gels enhance primordial } \\
\text { germ cell differentiation of embryonic } \\
\text { stem cells. }\end{array}$ \\
\hline & {$[34]$} & 2020 & Bone & $\begin{array}{c}\text { In vitro (rat MSC) / In vivo } \\
\text { (rat) }\end{array}$ & $\begin{array}{l}\text { The osteogenesis and mineralization were } \\
\text { observed when MSC were encapsulated into } \\
\text { alginate gels. }\end{array}$ \\
\hline & [35] & 2019 & Bone & $\begin{array}{l}\text { In vitro (murine bone calvaria } \\
\text { pre-osteoblast)/in vivo } \\
\text { (mouse) }\end{array}$ & $\begin{array}{c}\text { The osteoblast differentiation of pre-osteoblast } \\
\text { was high in vitro and in vivo by encapsulating } \\
\text { into alginate-gelatin injectable gels. }\end{array}$ \\
\hline & {$[36]$} & 2017 & Bone & $\begin{array}{l}\text { In vitro (human } \\
\text { adipose-derived MSC) }\end{array}$ & $\begin{array}{l}\text { The crosslinked oxidized alginate-gelatin } \\
\text { hydrogel was prepared by changing the } \\
\text { mixing ratio of alginate/gelatin. The ratio } \\
\text { influenced osteogenic differentiation. }\end{array}$ \\
\hline & [37] & 2018 & None & $\begin{array}{l}\text { In vitro (human bone } \\
\text { marrow-derived MSC) }\end{array}$ & $\begin{array}{l}\text { Preparation of dual crosslinking homogeneous } \\
\text { alginate microspheres combined with a } \\
\text { microfluidics system to encapsulate MSC. }\end{array}$ \\
\hline & [38] & 2018 & Pancreas & $\begin{array}{c}\text { In vitro (human pancreatic } \\
\text { islets) }\end{array}$ & $\begin{array}{l}\text { The first trial to encapsulate human pancreatic } \\
\text { islets in a dynamic condition, such as an } \\
\text { organ-on-chip. }\end{array}$ \\
\hline & [39] & 2018 & Pancreas & $\begin{array}{l}\text { In vitro (mouse pancreatic } \beta \\
\text { cells) /In vivo (rat) }\end{array}$ & $\begin{array}{l}\text { Dual cross-linked alginate microbeads were } \\
\text { stable under the inflammation condition } \\
\text { in vitro and in vivo. }\end{array}$ \\
\hline & [40] & 2016 & Cancer & $\begin{array}{l}\text { In vitro (human breast cancer } \\
\text { cells and human fibroblasts) }\end{array}$ & $\begin{array}{c}\text { Alginate gels encapsulating human breast } \\
\text { cancer cells and fibroblasts replicated } \\
\text { phenotypic functions of cancer disease } \\
\text { progression in vitro. }\end{array}$ \\
\hline & [41] & 2016 & Cancer & $\begin{array}{l}\text { In vitro (human umbilical } \\
\text { cord-derived MSC and human } \\
\text { hepatocellular carcinoma) }\end{array}$ & $\begin{array}{c}\text { EMT induction or metastasis was observed } \\
\text { when the alginate gels encapsulating } \\
\text { hepatocellular carcinoma were co-cultured } \\
\text { with MSC. }\end{array}$ \\
\hline Chitosan & [42] & 2017 & Blood vessel & $\begin{array}{l}\text { In vitro (human dermal } \\
\text { fibroblast cells) }\end{array}$ & $\begin{array}{c}\text { Chitosan-gelatin-based bi-layer was an } \\
\text { appropriate scaffold to mimic the biological } \\
\text { blood vessel, such as morphology and } \\
\text { mechanism. }\end{array}$ \\
\hline
\end{tabular}


Table 1. Cont.

\begin{tabular}{|ccccc}
\hline Biomaterials & Ref. & Date & $\begin{array}{c}\text { Tissue } \\
\text { Targeted }\end{array}$ & $\begin{array}{c}\text { In Vitro (Cell Type)/In Vivo } \\
\text { (Animal Type) Testing }\end{array}$ \\
\hline$[43]$ & 2018 & Blood vessel & $\begin{array}{c}\text { In vitro (human lymphocyte } \\
\text { cell T) }\end{array}$ \\
\hline$[44]$ & 2019 & Blood vessel & $\begin{array}{c}\text { In vitro (endothelial } \\
\text { progenitor cells, red blood } \\
\text { cells, or platelet-rich } \\
\text { plasma)/In vivo (pig) }\end{array}$ \\
\hline$[45]$ & 2016 & Cartilage & $\begin{array}{c}\text { In vitro (mouse } \\
\text { pre-chondrocytes) }\end{array}$ \\
\hline [46] 2019 & Cartilage & In vitro (rabbit chondrocytes)
\end{tabular}

The properties of the tube showed the range value of native blood vessels (tensile strength: $2.13 \mathrm{MPa}$ and burst pressure: $2593 \mathrm{mmHg}$ ). In addition, the tube was of high hemocompatibility and low cytotoxicity.

A heparin-chitosan multilayered vascular patch was biocompatible, such as a low hemolysis rate.

The membrane of chitosan and chondroitin sulfate improved cell adhesion and enhance the expression of cartilage markers.

They evaluated the mechanical and biological properties of the poly

3-hydroxybutyrate-chitosan/silk scaffold for chondrocyte viability.

When the graphene oxide concentration in the chitosan scaffold was high, physical and mechanical properties were improved, resulting in enhanced proliferation of chondrocytes.

[47] 2019 Cartilage In vitro (human cartilage)

\begin{tabular}{|c|c|c|c|c|c|}
\hline & [48] & 2017 & Cartilage & $\begin{array}{l}\text { In vitro (mouse } \\
\text { pre-chondrocytes) }\end{array}$ & $\begin{array}{l}\text { Preparation of chitosan/poly(vinyl } \\
\text { alcohol)/graphene oxide nanofiber for } \\
\text { cartilage tissue engineering. }\end{array}$ \\
\hline & [49] & 2016 & Bone & $\begin{array}{l}\text { In vitro (human bone } \\
\text { osteosarcoma cells) }\end{array}$ & $\begin{array}{l}\text { Chitosan-montmorillonite-hydroxyapatite } \\
\text { composite scaffolds were non-cytotoxic, and } \\
\text { the properties, such as bioactivity or protein } \\
\text { absorption, were improved compared with } \\
\text { chitosan or chitosan-montmorillonite scaffolds. }\end{array}$ \\
\hline & [50] & 2017 & Bone & $\begin{array}{l}\text { In vitro (human bone } \\
\text { marrow-derived MSC) }\end{array}$ & $\begin{array}{l}\text { Chitosan nanohybrid combined with } \\
\text { strontium hydroxyapatite enhanced } \\
\text { osteoconductivity. }\end{array}$ \\
\hline & [51] & 2017 & $\begin{array}{l}\text { Intervertebral } \\
\text { disc }\end{array}$ & $\begin{array}{l}\text { In vitro (rabbit nucleus } \\
\text { pulposus cells from } \\
\text { lumbar disc) }\end{array}$ & $\begin{array}{l}\text { Chitosan-based injectable gels indicated } \\
\text { constant storage modulus similar to the } \\
\text { intervertebral disc ECM. }\end{array}$ \\
\hline & [52] & 2019 & $\begin{array}{l}\text { Intervertebral } \\
\text { disc }\end{array}$ & $\begin{array}{c}\text { In vitro (bovine nucleus } \\
\text { pulposus cells from coccygeal } \\
\text { intervertebral disc) }\end{array}$ & $\begin{array}{l}\text { Thermosensitive chitosan hydrogels with high } \\
\text { strength and rheological properties } \\
\text { were prepared. }\end{array}$ \\
\hline & [53] & 2019 & $\begin{array}{l}\text { Intervertebral } \\
\text { disc }\end{array}$ & $\begin{array}{l}\text { In vitro (rabbit nucleus } \\
\text { pulposus cells and annulus } \\
\text { fibrosus cells)/In vivo (rabbit) }\end{array}$ & $\begin{array}{l}\text { Preparation of chitosan hydrogel/poly } \\
\text { (butylene succinate-co-terephthalate) } \\
\text { copolyester electrospun fibers for } \\
\text { intervertebral disc therapy. }\end{array}$ \\
\hline & [54] & 2017 & Skin & $\begin{array}{l}\text { In vitro (mouse } \\
\text { fibroblast cells) }\end{array}$ & $\begin{array}{l}\text { Electrospun multilayer chitosan scaffolds with } \\
\text { low cytotoxicity were prepared. The scaffolds } \\
\text { have high porosity, and the mechanical } \\
\text { properties of the scaffolds matched those of the } \\
\text { human skin. }\end{array}$ \\
\hline & [55] & 2019 & Skin & $\begin{array}{l}\text { In vitro (mouse } \\
\text { fibroblast cells) }\end{array}$ & $\begin{array}{l}\text { The chitosan-vitamin } C \text { scaffolds with glycerol } \\
\text { and polyethylene glycol enhanced the activity } \\
\text { of skin cells. }\end{array}$ \\
\hline Silk fibroin & [56] & 2020 & Bone & $\begin{array}{c}\text { In vitro (rat bone } \\
\text { marrow-derived MSC) }\end{array}$ & $\begin{array}{l}\text { They evaluated the appropriate mixing ratio of } \\
\text { silk fibroin/gelatin as a microcarrier for } \\
\text { efficient osteogenic differentiation. }\end{array}$ \\
\hline
\end{tabular}


Table 1. Cont.

\begin{tabular}{|c|c|c|c|c|c|}
\hline Biomaterials & Ref. & Date & $\begin{array}{l}\text { Tissue } \\
\text { Targeted }\end{array}$ & $\begin{array}{l}\text { In Vitro (Cell Type)/In Vivo } \\
\text { (Animal Type) Testing }\end{array}$ & Results Featured \\
\hline & [57] & 2019 & Bone & $\begin{array}{l}\text { In vitro (human bone } \\
\text { marrow-derived MSC) }\end{array}$ & $\begin{array}{l}\text { Hydrogen sulfide-releasing silk fibroin } \\
\text { scaffolds induced osteogenesis. }\end{array}$ \\
\hline & {$[58]$} & 2016 & Cartilage & $\begin{array}{c}\text { In vitro (porcine } \\
\text { chondrocytes)/In vivo (rat) }\end{array}$ & $\begin{array}{l}\text { When the chondrocytes were cultured on the } \\
\text { silk fibroin scaffolds of Antheraea assamensis, } \\
\text { sulfated glycosaminoglycans and type II } \\
\text { collagen production increased. }\end{array}$ \\
\hline & [59] & 2017 & Cartilage & $\begin{array}{l}\text { In vitro (rat bone } \\
\text { marrow-derived } \\
\text { MSC)/In vivo (rabbit) }\end{array}$ & $\begin{array}{c}\text { They optimized the mixing ratio of silk fibroin } \\
\text { to gelatin as scaffolds prepared using 3D } \\
\text { printing for cartilage repair. }\end{array}$ \\
\hline & {$[60]$} & 2016 & Cartilage & $\begin{array}{l}\text { In vitro (pig auricular } \\
\text { chondrocytes) }\end{array}$ & $\begin{array}{l}\text { The combination of agarose and silk fibroin } \\
\text { enhanced the polymeric network, leading to } \\
\text { the up-regulation of cartilage-specific genes. }\end{array}$ \\
\hline & {$[61]$} & 2016 & $\begin{array}{l}\text { Tympanic } \\
\text { membrane }\end{array}$ & In vitro (pig cartilage) & $\begin{array}{l}\text { The first report on the effect of silk fibroin } \\
\text { membranes on the acoustic energy transfer } \\
\text { and tensile strength to cartilage. }\end{array}$ \\
\hline \multirow[t]{5}{*}{ Agarose } & {$[62]$} & 2021 & Skin & $\begin{array}{l}\text { In vitro (human normal } \\
\text { embryonic lung fibroblast } \\
\text { cells)/In vivo (mouse) }\end{array}$ & $\begin{array}{l}\text { Agarose-polydopamine hydrogels were } \\
\text { biocompatible scaffolds capable of promoting } \\
\text { collagen deposition and angiogenesis, finally } \\
\text { skin defect healing. }\end{array}$ \\
\hline & [63] & 2017 & Cartilage & $\begin{array}{l}\text { In vitro (human elastic } \\
\text { cartilage-derived } \\
\text { chondrocytes) }\end{array}$ & $\begin{array}{l}\text { Nanostructured fibrin-agarose hydrogel } \\
\text { enabled chondrocytes encapsulation and } \\
\text { support of culture. }\end{array}$ \\
\hline & {$[64]$} & 2019 & Nerve & In vitro (rat neuronal cells) & $\begin{array}{c}\text { Electrical stimulation facilitated } \\
\text { dexamethasone release from hydrogels. }\end{array}$ \\
\hline & [65] & 2017 & Nerve & $\begin{array}{l}\text { In vitro (rat adipose-derived } \\
\text { MSC)/In vivo (rat) }\end{array}$ & $\begin{array}{l}\text { Collagen conduits filled with fibrin-agarose } \\
\text { hydrogels containing stem cells were prepared } \\
\text { for nerve regeneration. }\end{array}$ \\
\hline & {$[66]$} & 2017 & Nerve & $\begin{array}{l}\text { In vitro (human } \\
\text { adipose-derived MSC) }\end{array}$ & $\begin{array}{l}\text { A nanostructured fibrin-agarose bioartificial } \\
\text { nerve substitute enabled stem cells } \\
\text { to proliferate. }\end{array}$ \\
\hline \multirow[t]{2}{*}{ Matrigel } & [67] & 2018 & Cancer & $\begin{array}{l}\text { In vitro (human breast cancer } \\
\text { cells) }\end{array}$ & $\begin{array}{l}\text { The cancer cell-laden gels composed of the } \\
\text { appropriate mixing ratio of Matrigel and } \\
\text { alginate replicate the behavior of cancer cells. }\end{array}$ \\
\hline & {$[68]$} & 2017 & Cancer & $\begin{array}{l}\text { In vitro (human non-small } \\
\text { cell lung carcinoma) }\end{array}$ & $\begin{array}{l}\text { Matrigel and collagen-based microfluidics } \\
\text { systems can control the migration of cancer } \\
\text { cells by changing the Matrigel concentration. }\end{array}$ \\
\hline \multirow[t]{4}{*}{$\begin{array}{l}\text { Poly(lactic } \\
\text { acid) (PLA) }\end{array}$} & [69] & 2019 & Bone & $\begin{array}{l}\text { In vitro (mouse embryonic } \\
\text { osteoblast cells) }\end{array}$ & $\begin{array}{l}\text { The attachment and proliferation of cells on } \\
\text { poly(lactic acid)-hydroxyapatite (HA) hybrid } \\
\text { scaffolds increased. The result is mainly } \\
\text { because of the interaction between cells and } \\
\text { scaffolds via HA. }\end{array}$ \\
\hline & [70] & 2020 & Bone & $\begin{array}{l}\text { In vitro (cat bone } \\
\text { marrow-derived } \\
\text { MSC)/In vivo (mouse) }\end{array}$ & $\begin{array}{l}\text { PLA-HA improved the adhesion of cells, and } \\
\text { widespread ingrowth of tissues into the } \\
\text { implant pores was observed. }\end{array}$ \\
\hline & [71] & 2020 & Bone & None & $\begin{array}{l}\text { Microanalysis of PLA-HA scaffolds } \\
\text { was performed. }\end{array}$ \\
\hline & [72] & 2021 & Bone & $\begin{array}{l}\text { In vitro (human fetal } \\
\text { osteoblast cells) }\end{array}$ & $\begin{array}{l}\text { PLA-based scaffolds provided porous } \\
\text { networks and gave cells good biological } \\
\text { functions, such as osteogenesis. }\end{array}$ \\
\hline
\end{tabular}


Table 1. Cont.

\begin{tabular}{|c|c|c|c|c|c|}
\hline Biomaterials & Ref. & Date & $\begin{array}{l}\text { Tissue } \\
\text { Targeted }\end{array}$ & $\begin{array}{l}\text { In Vitro (Cell Type)/In Vivo } \\
\text { (Animal Type) Testing }\end{array}$ & Results Featured \\
\hline & [73] & 2021 & Bone & $\begin{array}{l}\text { In vitro (rabbit MSC) /In vivo } \\
\text { (rabbit) }\end{array}$ & $\begin{array}{l}\text { PLA scaffolds incorporating a high } \\
\text { concentration of HA showed efficient bone } \\
\text { regeneration. }\end{array}$ \\
\hline \multirow[t]{6}{*}{$\begin{array}{l}\text { Poly(lactic-co- } \\
\text { glycolic acid) } \\
\text { (PLGA) }\end{array}$} & [74] & 2018 & Bone & $\begin{array}{l}\text { In vitro (human osteosarcoma } \\
\text { cells)/In vivo (rabbit) }\end{array}$ & $\begin{array}{l}\text { The amount of bone formation for } \mathrm{TiO}_{2} \\
\text { nanotube/PLGA scaffolds was much higher } \\
\text { than for PLGA scaffolds. }\end{array}$ \\
\hline & [75] & 2021 & Bone & $\begin{array}{l}\text { In vitro (human adipose or } \\
\text { bone marrow-derived } \\
\text { MSC)/In vivo (rat) }\end{array}$ & $\begin{array}{l}\text { PLGA-hydroxyapatite (HA) nanoparticles } \\
\text { promoted osteodifferentiation compared to the } \\
\text { PLGA scaffold. }\end{array}$ \\
\hline & [76] & 2019 & Cartilage & $\begin{array}{c}\text { In vitro (rabbit } \\
\text { synovium-resident } \\
\text { MSC)/In vivo (rabbit) }\end{array}$ & $\begin{array}{l}\text { Bone morphogenetic proteins-7 loaded fibrous } \\
\text { PLGA scaffolds combined with MSC showed a } \\
\text { cartilage formation. }\end{array}$ \\
\hline & [77] & 2020 & Cartilage & $\begin{array}{l}\text { In vitro (rabbit bone } \\
\text { marrow-derived MSC and } \\
\text { rabbit chondrocytes) }\end{array}$ & $\begin{array}{l}\text { When cells were cultured on insulin-like } \\
\text { growth factor-1 laden } \\
\text { PLGA/polydopamine/poly- } \varepsilon \text {-caprolactone } \\
\text { scaffolds, glycosaminoglycan content, } \\
\text { chondrogenic protein, and gene } \\
\text { expression increased. }\end{array}$ \\
\hline & [78] & 2017 & Nerve & $\begin{array}{l}\text { In vitro (rat bone } \\
\text { marrow-derived MSC) }\end{array}$ & $\begin{array}{l}\text { PLGA microcarriers were promising scaffolds } \\
\text { to support the culture of } \\
\text { neurotrophin-3-overexpressing stem cells. }\end{array}$ \\
\hline & [79] & 2018 & Nerve & $\begin{array}{l}\text { In vitro (rat bone } \\
\text { marrow-derived MSC and rat } \\
\text { cortical neurons) }\end{array}$ & $\begin{array}{l}\text { Stem cells and neurons could grow and } \\
\text { migrate in the PLGA scaffolds. }\end{array}$ \\
\hline
\end{tabular}

\subsection{Collagen}

Collagen is the most abundant protein in the body and supports mechanical and structural conditions [80]. Collagen is mainly composed of glycine, proline, or hydroxyproline. A hydrogen bond forms the collagen triple helix. The main types of collagen are type I (skin, tendon, or bone), II (cartilage), III (skin vessel), and IV (basement membrane) [81]. Due to the abundant existing ratio, collagen is an essential protein for cells to enhance cell function [82]. For example, collagen crosslinking and stiffening promotes the aggregates of breast cancer [83], therefore, collagen is widely used as a material for the tissue engineering of skin [84], bone [16,17,85], cartilage [18,86], blood vessels [87], muscle [19], or cancer [20-22]. For example, when mesenchymal stem cells (MSC) are cultured on Type I collagen gels, the osteoblast marker, such as alkaline phosphatase activity, collagen synthesis, or osteocalcin gene, is enhanced [85].

The composite of collagen and biphasic calcium phosphate nanoparticles with a controlled release of dexamethasone has also been prepared. The material enables efficient bone tissue regeneration from MSC in vitro. High bone regeneration is observed when the materials are injected into the dorsal of athymic nude mice [16]. Heo et al. prepared collagen hydrogel encapsulating multicellular spheroids of MSC and human umbilical vein endothelial cells. The spheroid showed cell spreading, proliferation, osteogenic differentiation, and pre-vascular network in the hydrogel because collagen gel provides cells a suitable environment [17]. Collagen material is specially selected in the threedimensional culture of cancer cells to evaluate migration, invasion, or metastasis because the cancer cells prefer to migrate into type I collagen in vivo [88]. There is a report that the degree of collagen fiber alignment or the fibril bending stiffness of the collagen matrix affects the behavior of breast cancer cells [23]. Moreover, when lung or pancreatic cells were co-cultured with fibroblasts into collagen gels, cancer cells migrated efficiently [22]. Recently, to investigate the reaction of $\mathrm{T}$ cells under the tumor microenvironment, $\mathrm{T}$ 
cells are cultured with collagen gels of different densities [89]. Indeed, collagen is the most representative biomaterial. Researchers will continue studying the effect of collagen material on biological function in vitro and in vivo.

\subsection{Gelatin}

Collagen material is effective because collagen is a prominent ECM component. However, there is a limitation of collagen as a biomaterial due to its low solubility in water and biological activities. Gelatin, a denatured form of collagen, as water-soluble material, is often used in biomedical approaches [90]. Gelatin hydrogels can permeate the oxygen or nutrient because of the high water content [91,92] — this permeability is effective in regenerative medicine. For example, cells present in the center of spheroids or the center layer of the multilayer cell sheet are dead with hypoxia [93]. Tabata et al. have incorporated the gelatin hydrogels into the spheroids or between each cell sheet to tackle this problem. This method enables the culture of the spheroids or cell sheets for an extended period [24,26-28]. The gelatin hydrogels not only permeate oxygen but also contain growth factors $[25,29,30]$. As mentioned above, growth factors are essential to enhance cell activity. When the gelatin hydrogels containing basic fibroblasts growth factors (bFGF) were injected into damaged tissues, effective vascularization was observed, resulting in tissue regeneration [94,95]. There are two advantages of the gelatin hydrogel microspheres; one is the drug release mechanism. The growth factors are released from the materials not by diffusion but by the degradation of materials with degradation enzymes, which means the drug is released sustainably when injecting the gelatin materials into damaged tissues. The other is the eventual disappearance of the gelatin hydrogel microspheres. To repair the damaged or injured tissues, cells near the damaged tissues should migrate, proliferate, and differentiate. The material-remaining leads to the physical impairment of tissue regeneration [1]. Therefore, the materials injected must disappear during tissue regeneration. The gelatin hydrogel microspheres disappear eventually, and the degradation speed can be changed and modified by the chemical crosslinking condition, responding to the damage level [95].

The gelatin hydrogel microspheres are also effective in drug discovery. Cancer invasion is one of the issues to be solved [96]. The cancer invasion model would be effective in anti-cancer drug screening. It is well known that the interaction between cancer cells and stromal cells, especially cancer-associated fibroblasts (CAF), promotes cancer invasion [97]. 3D CAF aggregates incorporating gelatin hydrogel microspheres capable of drug release are prepared to mimic the cancer invasion. The CAF aggregates increase the invasion rate of cancer cells [6,31,32], herefore, the characteristics of gelatin hydrogel microspheres, such as oxygen permeability, drug release mechanisms, or eventual disappearance, are desirable for building a cancer tissue model for the screening of anti-cancer drugs.

In addition to hydrogels, gelatin hydrogel nonwoven fabrics have also been recently reported. The mechanical properties of the gelatin hydrogel nonwoven fabrics are strong enough to be handled in swollen conditions [98-100]. When multilayered cell sheets are cultured with the gelatin hydrogel nonwoven fabric, the transfer time of the cell sheets is improved. In addition, glucose consumption or adenosine triphosphate (ATP) production of multilayered cell sheets enhances by formulating with the gelatin hydrogel nonwoven fabrics between each cell sheet [99].

Moreover, cationized gelatin nanospheres incorporating imaging probes to detect mRNA have been recently prepared [101]. For cell transplantation, the non-invasive technology to detect the cellular localization and distribution or biological function after transplantation is needed. The nanospheres aim to visualize cellular function, such as apoptosis [102], macrophage phenotypes [103], or cell proliferation ability [104].

\subsection{Alginate}

Alginate, a copolymer of $\alpha$-L-guluronic acid and $\beta$-D-mannuronic acid, is derived from seaweed [105]. Alginate is one of the attractive biomaterials in biomedical engineering because the molecular structure of alginate is similar to that of polysaccharides [106]. In 
addition, alginate gels are easily obtained by calcium or ferric ion at room temperature, and cell encapsulation into alginate gels has been extensively studied $[107,108]$. These gels, which incorporate cells, are effective for cell delivery to damaged tissues or in vitro cell research. In particular, stem cells [33,34,36,37,109-111], pancreatic-associated cells [38,39,112], or cancer cells $[40,41]$ are often selected in the alginate encapsulation system. For example, An et al. encapsulated MSC into alginate gels. The systems showed efficient differentiation into osteoblast cells [34]. Mansouri et al. reported that alginate gels promote the differentiation into primordial germ cells of mouse embryonic stem cells [33]. Somo et al. prepared MIN6 of a pancreatic beta-cell line encapsulated into alginate gels to deliver to islets as a type 1 diabetes treatment [39], while Estrada et al. prepared alginate gels encapsulating breast cancer cells and fibroblasts cells to mimic the breast cancer microenvironment. As a result, the reduction in estrogen receptors, the loss of cell polarity, the increase of cancer cell migration, and enhanced angiogenesis potential were observed in this system [40]. Thus, a cell encapsulating system based on alginate gels is effective in tissue engineering or drug research.

Injectable gels for cell transplantation, taking advantage of cell encapsulating, have been reported. Injectable alginate and gelatin hydrogels containing cells are prepared by mixing alginate/gelatin solution and $\mathrm{FeCl}_{3}$ solution based on the physico-chemical interaction. They confirm the appropriate mixing ratio of alginate and gelatin for cell cytotoxicity, cell proliferation, and differentiation in vitro and in vivo. The strength of these injectable gels is to form gelation by not chemically or covalently crosslinking polymers but by physicochemical interaction. This crosslinking allows the gel to disintegrate quickly. It disappears a few days after the injection, while most injectable gels already reported take more than three weeks to disappear or even remain in the body due to the stable chemical crosslinking [35]. The disappearance characteristics of injectable alginate-based gels are suitable for tissue regeneration because the material that may remain for a long time sometimes causes the physical impairment of tissue regeneration.

\subsection{Chitosan}

Chitosan, a copolymer of $\beta$-(1 $\rightarrow 4)$-2-acetamido-D-glucose and $\beta$-(1 $\rightarrow 4)$-2-amino-Dglucose units, is obtained by deacetylation of chitin [113]. The solubility of chitosan is much higher than that of chitin, which means that it is easy to handle. Chitosan is easily chemically modified because of the existence of $\beta-(1,4)$ glycosidic bonds between D-glucosamine and N-acetyl-D-glucosamine [114]. Such modifications are used for imparting stiffness or low inflammatory induction property to chitosan [115]. Chitosan can also interact with negatively charged biomaterials $[10,116]$. Due to the low cost and versatility, chitosan is effective biomaterial as food packaging films [113,117], preservation of food [118] and drink [119], pharmaceutical science [120], cosmetics [121], or antibacterial agents [115]. In regenerative medicine, chitosan is often selected for blood vessels [42-44], cartilage $[45-48,122-124]$, bone $[49,50,125,126]$, the intervertebral disc $[51-53,127,128]$, or skin $[54,55,129]$ regeneration. For example, glycosaminoglycan (GAG) is essential to stimulate the formation of cartilage. The electronic interaction between the negatively charged GAG and chitosan is formed. GAG amount of cartilage cells with chitosan scaffold was higher 14 or 21 days after the transplantation [122]. In addition to the interaction with GAG, the structure of chitosan is close to that of GAG. Therefore, the chitosan scaffold can support cell culture because GAG is one of the most critical ECM components [11]. Chitosan scaffold enables human fibroblasts, endothelial cells, or keratinocytes to proliferate in vitro and in vivo [130]. As one trial for blood vessel regeneration, heparin and chitosan scaffold have been reported. Zhang et al. have prepared a multilayered vascular patch by alternately depositing the heparin-chitosan onto a polyurethane-coated decellularized platform via a layer-by-layer method. The vascular patch has a capacity for vascular tissue regeneration in vitro and in vivo [44]. Due to the biocompatibility and positively charged surface, chitosan is one of the most effective biomaterials for regenerative medicine. 


\subsection{Silk Fibroin}

Silk is composed of fibroin (75\%) and sericin (25\%) [131]. Silk fibroin is a semicrystalline structured protein and therefore has a role in load-bearing capacity, while sericin is an amorphous structured polymer [132]. For the use of tissue engineering, sericin has some unfavorable properties. First of all, sericin reduces the mechanical strength of silk fibroin fiber. The modulus of silk without sericin has about twice mechanical strength as sericin included [133]. Second, although it isn't always necessary to be avoided, sericin sometimes induces an inflammatory response [134-136]. For the reasons, sericin is often removed by a degumming process under the boiling alkaline condition [137]. Silk fibroin is composed of H-chain $(\mathrm{Mw}=391.6 \mathrm{kDa})$ and L-chain $(\mathrm{Mw}=25.2 \mathrm{kDa})$. The two chains interact with each other by the disulfide bond, leading to the formation of the H-L complex [138]. Proteolytic enzymes, such as chymotrypsin, actinase, and carboxylase, degrade the silk fibroin. In addition, the degraded fraction does not induce an immunogenic response [139]. Due to the biocompatibility or biodegradability, silk fibroin is a useful biomaterial for the tissue engineering of bone [56,57,140], cartilage [58-60,141], tendon [142], skin [143,144], tympanic membrane [61], or blood vessel [145]. For example, when MSC are cultured on the silk fibroin scaffold, osteogenesis differentiation is enhanced [140]. In 2019, a silk fibroin scaffold capable of hydrogen sulfide release was prepared. This material enhances the osteogenesis of MSC, angiogenesis, or mineral matrix deposition [57]. The silk-gelatin microcarrier also achieves the osteogenic differentiation of MSC. The differentiation efficiency is comparable to that on commercial microbeads, Cultispher-S gelatin microspheres [56]. Moreover, the combination of silk fibroin and gelatin can retain the MSC, act as a physical barrier for blood clots, and provide mechanical protection of neocartilage formation [59].

\subsection{Agarose}

Agarose with a molecular weight of around $12 \mathrm{kDa}$ is composed of the unit of Dgalactose and 3.6-anhydro-L-galactopyranose [146]. Agarose has a capacity for water absorption, and therefore, it can permeate oxygen and nutrients to the encapsulated living cells [147]. In addition, agarose gels are formed by hydrogen bonding and electronic interaction without any harmful crosslinking agents [148]. Moreover, it has been reported that agarose doesn't show immunogenicity [149]. Besides, the tunable properties are suitable for the application of tissue engineering because different stiffness is required depending on where it's used. [146]. Therefore, some researchers try to use an agarose gel for the application of regenerative medicine. For example, agarose gel with the addition of polydopamine increases the water content and cell adhesion. As a result, the deposition of collagen and angiogenesis is enhanced [62]. Agarose gels containing cartilage cells with various cell seeding densities can investigate the precipitation of proteoglycan and GAG, which are the characteristics of cartilage [63]. Besides, regenerative medicine for nerve [64-66] or cornea [150] has been studied based on agarose.

\subsection{Matrigel}

The basement membrane comprises type IV collagen, laminin, heparan sulfate, growth factors, cytokines, or chemokines [151]. Cancer cells are attached to the basement membrane as alternative epithelial cells. Due to the basement membrane integrity, the separation between epithelial and stromal sites is achievable [152]. Cancer cells start to penetrate through the basement membrane for cancer invasion, degraded by several secreted factors, such as matrix metalloproteinase [31,153]. Therefore, the basement membrane is vital for cancer cells to enhance their biological functions. Despite the importance, human complete basement membrane can't be constructed with current scientific technology. Therefore, as an alternative material to the basement membrane, Matrigel is often used. Matrigel is a complex protein mixture of mouse Engelbreth-Holm-Swarm tumor [32,154]. Matrigel is effective in invasion assays of cancer cells, such as Boyden chamber or transwell [155]. In addition, Matrigel is also useful for the evaluation of the morphology of cancer cells. It has been reported that there is a good relationship between the morphology of cancer 
cells and the profile of gene expression [156]. The combination with other biomaterials has already been studied. For example, 3D alginate and Matrigel hydrogel keep human high invasive breast cancer cells with high malignancy, spreading, migration, or invasion activities similar to those observed in vivo [67]. Furthermore, when the hydrogels are prepared by changing the mixing ratio of collagen and Matrigel, fiber diameter or pore number could be modified. This enables the evaluation of cancer cell migration into the biomimetic matrix [68]. Taken together, Matrigel is one of the most valuable biomaterials to support the culture of cancer cells with characters similar to in vivo, and Matrigel-assisted tissue engineering is also promising in cancer tissue engineering and anti-cancer drug validation among regenerative medicine.

\subsection{Poly(lactic acid)}

The elastic modulus of poly(lactic acid) (PLA) is similar to that of bone, and PLA has good thermal processability [157-160]. Therefore, PLA is used for bone tissue engineering. Significantly, the combination of hydroxyapatite (HA) and PLA is often studied because HA has an important role in ECM remodeling and homeostasis [161]. PLA-HA scaffolds, which have a porosity of more than $85 \%$, have been prepared. The scaffolds have been used for the efficient culture of mouse embryonic osteoblasts cells because of the excellent HA distribution on the surface [69]. Zimina et al. report that the adhesion of MSC is about three times higher than that of the pure PLA sample mainly because the HA could increase the wettability of the polymeric biomaterial [70]. To scientifically support the PLA-HA scaffold, microanalysis [71] or 3D printing technology [72,73] has been recently studied.

\subsection{Poly(lactic-co-glycolic acid)}

Poly(lactic-co-glycolic acid) (PLGA) is a copolymer of polylactic acid and polyglycolic acid. Due to this composition, it tends to degrade more quickly than PLA. It is easy to modify the PLGA property such as degradability because the ratio of lactic acid and glycolic acid or molecular weight are the most critical factors to determine the properties [162]. In addition, PLGA formulation is prepared by simple methods, such as the solvent evaporation method or spray drying method [163]. For example, PLGA nanoparticles can be prepared by the solvent evaporation method as follows; PLGA and a hydrophobic drug are dissolved in an organic solvent, such as acetone or dichloromethane. The solution is added to aqueous poly(vinyl alcohol) solution to obtain the $\mathrm{O} / \mathrm{W}$ emulsion. Then, the $\mathrm{O} / \mathrm{W}$ emulsion is stirred overnight to evaporate organic solvent. The obtained particles can be directly used for various researches. Due to its biodegradability, biocompatibility, or ease of handle, PLGA is widely used in medical fields. For example, PLGA microparticles containing leuprolide are used to treat breast or prostate cancer [164]. PLGA is often selected for tissue engineering, especially for the brain or neuron [165]. Moradian et al. prepare PLGA microspheres to support the culture of neurotrophin-3 (NT-3) overexpressing cells. As a result, dopamine production and cell viability increased [78]. When MSC and nerve cells are cultured on a PLGA scaffold, both two cells proliferate and migrate. This tool is promising in the treatment of brain injury [79]. The conduit composed of PLGA promotes the Schwann cells, which stimulate axonal growth, leading to reduced cyst formation or damages [166]. In addition to the PLGA tube, the combination with salidroside promotes peripheral nerve regeneration in vitro and in vivo [167].

\section{Conclusions and Future Perspectives}

Regenerative medicine consists of the following four fields; cell transplantation, tissue engineering, drug research, and gene therapy. In each area, "utilization of cells with high activity" is essential. Therefore, the scientific methodologies to enhance cell activity contribute to regenerative medicine. In addition, although the interaction of biomaterials and targeted cells is focused in this review, the interaction of biomaterials and immune cells near the targeted cells (e.g., neutrophils or macrophages) is also an important factor because this interaction leads to the immune response. For example, macrophages are polarized 
to M1 (pro-inflammatory) and M2 (anti-inflammatory) phenotypes, responding to the environmental condition [168]. Therefore, when the biomaterials induce the modification of M1 macrophages, tissue regeneration would not be achieved. Moreover, the relationship between nanomaterials and immune cells has been recently investigated to understand the production of bio-corona, immune sensing, immune evasion, or degradation $[169,170]$. Based on these prospective, to further develop biomaterials-based regenerative medicine, the reaction of immune cells should be considered.

Author Contributions: Conceptualization, T.N. and Y.K.; writing-original draft preparation, T.N. and Y.K.; writing-review and editing, T.N. and Y.K. Both authors have read and agreed to the published version of the manuscript. All authors have read and agreed to the published version of the manuscript.

Funding: This research received no external funding.

Institutional Review Board Statement: Not applicable.

Informed Consent Statement: Not applicable.

Conflicts of Interest: The authors declare no conflict of interest.

\section{References}

1. Nii, T.; Makino, K.; Tabata, Y. Three-dimensional culture system of cancer cells combined with biomaterials for drug screening. Cancers 2020, 12, 2754. [CrossRef]

2. Fukuda, J.; Sakai, Y.; Nakazawa, K. Novel hepatocyte culture system developed using microfabrication and collagen/polyethylene glycol microcontact printing. Biomaterials 2006, 27, 1061-1070. [CrossRef] [PubMed]

3. Hauser, S.; Jung, F.; Pietzsch, J. Human Endothelial Cell Models in Biomaterial Research. Trends Biotechnol. 2017, 35, $265-277$. [CrossRef]

4. Rodríguez-Enríquez, S.; Gallardo-Pérez, J.C.; Avilés-Salas, A.; Marín-Hernández, A.; Carreño-Fuentes, L.; Maldonado-Lagunas, V.; Moreno-Sánchez, R. Energy metabolism transition in multi-cellular human tumor spheroids. J. Cell. Physiol. 2008, 216, 189-197. [CrossRef] [PubMed]

5. Asada, N.; Kunisaki, Y.; Pierce, H.; Wang, Z.; Fernandez, N.F.; Birbrair, A.; Ma'ayan, A.; Frenette, P.S. Differential cytokine contributions of perivascular haematopoietic stem cell niches. Nat. Cell Biol. 2017, 19, 214-223. [CrossRef] [PubMed]

6. Nii, T.; Makino, K.; Tabata, Y. A cancer invasion model of cancer-associated fibroblasts aggregates combined with TGF- $\beta 1$ release system. Regen. Ther. 2020, 14, 196-204. [CrossRef] [PubMed]

7. Breslin, S.; O'Driscoll, L. Three-dimensional cell culture: The missing link in drug discovery. Drug Discov. Today 2013, 18, 240-249. [CrossRef]

8. Ramadan, Q.; Zourob, M. Organ-on-a-chip engineering: Toward bridging the gap between lab and industry. Biomicrofluidics 2020, 14, 041501. [CrossRef] [PubMed]

9. Brighi, C.; Cordella, F.; Chiriatti, L.; Soloperto, A.; Di Angelantonio, S. Retinal and Brain Organoids: Bridging the Gap Between in vivo Physiology and in vitro Micro-Physiology for the Study of Alzheimer's Diseases. Front. Neurosci. 2020, 14, 655. [CrossRef]

10. Bakshi, P.S.; Selvakumar, D.; Kadirvelu, K.; Kumar, N.S. Chitosan as an environment friendly biomaterial-A review on recent modifications and applications. Int. J. Biol. Macromol. 2020, 150, 1072-1083. [CrossRef]

11. Croisier, F.; Jérôme, C. Chitosan-based biomaterials for tissue engineering. Eur. Polym. J. 2013, 49, 780-792. [CrossRef]

12. Reddy, M.S.B.; Ponnamma, D.; Choudhary, R.; Sadasivuni, K.K. A comparative review of natural and synthetic biopolymer composite scaffolds. Polymers 2021, 13, 1105. [CrossRef] [PubMed]

13. Hinderer, S.; Layland, S.L.; Schenke-Layland, K. ECM and ECM-like materials-Biomaterials for applications in regenerative medicine and cancer therapy. Adv. Drug Deliv. Rev. 2016, 97, 260-269. [CrossRef]

14. Lee, Y.B.; Kim, E.M.; Byun, H.; Chang, H.k.; Jeong, K.; Aman, Z.M.; Choi, Y.S.; Park, J.; Shin, H. Engineering spheroids potentiating cell-cell and cell-ECM interactions by self-assembly of stem cell microlayer. Biomaterials 2018, 165, 105-120. [CrossRef]

15. Sainio, A.; Järveläinen, H. Extracellular matrix-cell interactions: Focus on therapeutic applications. Cell. Signal. 2020, 66, 109487. [CrossRef] [PubMed]

16. Chen, Y.; Kawazoe, N.; Chen, G. Preparation of dexamethasone-loaded biphasic calcium phosphate nanoparticles/collagen porous composite scaffolds for bone tissue engineering. Acta Biomater. 2018, 67, 341-353. [CrossRef]

17. Heo, D.N.; Hospodiuk, M.; Ozbolat, I.T. Synergistic interplay between human MSCs and HUVECs in 3D spheroids laden in collagen/fibrin hydrogels for bone tissue engineering. Acta Biomater. 2019, 95, 348-356. [CrossRef] [PubMed]

18. Li, H.; Chen, R.; Jia, Z.; Wang, C.; Xu, Y.; Li, C.; Xia, H.; Meng, D. Porous fish collagen for cartilage tissue engineering. Am. J. Transl. Res. 2020, 12, 6107-6121.

19. Chen, S.; Kawazoe, N.; Chen, G. Biomimetic Assembly of Vascular Endothelial Cells and Muscle Cells in Microgrooved Collagen Porous Scaffolds. Tissue Eng.-Part C Methods 2017, 23, 367-376. [CrossRef] 
20. Campbell, J.J.; Husmann, A.; Hume, R.D.; Watson, C.J.; Cameron, R.E. Development of three-dimensional collagen scaffolds with controlled architecture for cell migration studies using breast cancer cell lines. Biomaterials 2017, 114, 34-43. [CrossRef]

21. Saini, H.; Rahmani Eliato, K.; Silva, C.; Allam, M.; Mouneimne, G.; Ros, R.; Nikkhah, M. The Role of Desmoplasia and Stromal Fibroblasts on Anti-cancer Drug Resistance in a Microengineered Tumor Model. Cell. Mol. Bioeng. 2018, 11, 419-433. [CrossRef] [PubMed]

22. Miyazaki, K.; Oyanagi, J.; Hoshino, D.; Togo, S.; Kumagai, H.; Miyagi, Y. Cancer cell migration on elongate protrusions of fibroblasts in collagen matrix. Sci. Rep. 2019, 9, 1-15. [CrossRef] [PubMed]

23. Sapudom, J.; Kalbitzer, L.; Wu, X.; Martin, S.; Kroy, K.; Pompe, T. Fibril bending stiffness of 3D collagen matrices instructs spreading and clustering of invasive and non-invasive breast cancer cells. Biomaterials 2019, 193, 47-57. [CrossRef] [PubMed]

24. Matsuo, T.; Masumoto, H.; Tajima, S.; Ikuno, T.; Katayama, S.; Minakata, K.; Ikeda, T.; Yamamizu, K.; Tabata, Y.; Sakata, R.; et al. Efficient long-term survival of cell grafts after myocardial infarction with thick viable cardiac tissue entirely from pluripotent stem cells. Sci. Rep. 2015, 5, 1-14. [CrossRef]

25. Li, Z.; Masumoto, H.; Jo, J.I.; Yamazaki, K.; Ikeda, T.; Tabata, Y.; Minatoya, K. Sustained release of basic fibroblast growth factor using gelatin hydrogel improved left ventricular function through the alteration of collagen subtype in a rat chronic myocardial infarction model. Gen. Thorac. Cardiovasc. Surg. 2018, 66, 641-647. [CrossRef]

26. Tajima, S.; Tabata, Y. Preparation of EpH4 and 3T3L1 cells aggregates incorporating gelatin hydrogel microspheres for a cell condition improvement. Regen. Ther. 2017, 6, 90-99. [CrossRef]

27. Tajima, S.; Tabata, Y. Preparation of epithelial cell aggregates incorporating matrigel microspheres to enhance proliferation and differentiation of epithelial cells. Regen. Ther. 2017, 7, 34-44. [CrossRef]

28. Inoo, K.; Bando, H.; Tabata, Y. Enhanced survival and insulin secretion of insulinoma cell aggregates by incorporating gelatin hydrogel microspheres. Regen. Ther. 2018, 8, 29-37. [CrossRef] [PubMed]

29. Tanaka, A.; Nakamura, H.; Tabata, Y.; Fujimori, Y.; Kumasawa, K.; Kimura, T. Effect of sustained release of basic fibroblast growth factor using biodegradable gelatin hydrogels on frozen-thawed human ovarian tissue in a xenograft model. J. Obstet. Gynaecol. Res. 2018, 44, 1947-1955. [CrossRef]

30. Notodihardjo, S.C.; Morimoto, N.; Kakudo, N.; Mitsui, T.; Le, T.M.; Tabata, Y.; Kusumoto, K. Efficacy of Gelatin Hydrogel Impregnated with Concentrated Platelet Lysate in Murine Wound Healing. J. Surg. Res. 2019, 234, 190-201. [CrossRef] [PubMed]

31. Nii, T.; Makino, K.; Tabata, Y. A Cancer Invasion Model Combined with Cancer-Associated Fibroblasts Aggregates Incorporating Gelatin Hydrogel Microspheres Containing a p53 Inhibitor. Tissue Eng.-Part C Methods 2019, 25, 711-720. [CrossRef] [PubMed]

32. Nii, T.; Kuwahara, T.; Makino, K.; Tabata, Y. A co-culture system of three-dimensional tumor-associated macrophages and three-dimensional cancer-associated fibroblasts combined with biomolecule release for cancer cell migration. Tissue Eng.-Part $A$ 2020, 26, 1272-1282. [CrossRef]

33. Mansouri, V.; Salehi, M.; Omrani, M.d.; Niknam, Z.; Ardeshirylajimi, A. Collagen-alginate microspheres as a 3D culture system for mouse embryonic stem cells differentiation to primordial germ cells. Biologicals 2017, 48, 114-120. [CrossRef] [PubMed]

34. An, C.; Liu, W.; Zhang, Y.; Pang, B.; Liu, H.; Zhang, Y.; Zhang, H.; Zhang, L.; Liao, H.; Ren, C.; et al. Continuous microfluidic encapsulation of single mesenchymal stem cells using alginate microgels as injectable fillers for bone regeneration. Acta Biomater. 2020, 111, 181-196. [CrossRef] [PubMed]

35. Anamizu, M.; Tabata, Y. Design of injectable hydrogels of gelatin and alginate with ferric ions for cell transplantation. Acta Biomater. 2019, 100, 184-190. [CrossRef]

36. Sarker, B.; Zehnder, T.; Rath, S.N.; Horch, R.E.; Kneser, U.; Detsch, R.; Boccaccini, A.R. Oxidized Alginate-Gelatin Hydrogel: A Favorable Matrix for Growth and Osteogenic Differentiation of Adipose-Derived Stem Cells in 3D. ACS Biomater. Sci. Eng. 2017, 3, 1730-1737. [CrossRef] [PubMed]

37. Etter, J.N.; Karasinski, M.; Ware, J.; Oldinski, R.A. Dual-crosslinked homogeneous alginate microspheres for mesenchymal stem cell encapsulation. J. Mater. Sci. Mater. Med. 2018, 29, 1-10. [CrossRef]

38. Acarregui, A.; Ciriza, J.; Saenz del Burgo, L.; Gurruchaga Iribar, H.; Yeste, J.; Illa, X.; Orive, G.; Hernández, R.M.; Villa, R.; Pedraz, J.L. Characterization of an encapsulated insulin secreting human pancreatic beta cell line in a modular microfluidic device. $J$. Drug Target. 2018, 26, 36-44. [CrossRef]

39. Somo, S.I.; Langert, K.; Yang, C.Y.; Vaicik, M.K.; Ibarra, V.; Appel, A.A.; Akar, B.; Cheng, M.H.; Brey, E.M. Synthesis and evaluation of dual crosslinked alginate microbeads. Acta Biomater. 2018, 65, 53-65. [CrossRef]

40. Estrada, M.F.; Rebelo, S.P.; Davies, E.J.; Pinto, M.T.; Pereira, H.; Santo, V.E.; Smalley, M.J.; Barry, S.T.; Gualda, E.J.; Alves, P.M.; et al. Modelling the tumour microenvironment in long-term microencapsulated 3D co-cultures recapitulates phenotypic features of disease progression. Biomaterials 2016, 78, 50-61. [CrossRef]

41. Liu, C.; Liu, Y.; Xu, X.X.; Guo, X.; Sun, G.W.; Ma, X.J. Mesenchymal stem cells enhance the metastasis of 3D-cultured hepatocellular carcinoma cells. BMC Cancer 2016, 16, 566. [CrossRef]

42. Badhe, R.V.; Bijukumar, D.; Chejara, D.R.; Mabrouk, M.; Choonara, Y.E.; Kumar, P.; du Toit, L.C.; Kondiah, P.P.D.; Pillay, V. A composite chitosan-gelatin bi-layered, biomimetic macroporous scaffold for blood vessel tissue engineering. Carbohydr. Polym. 2017, 157, 1215-1225. [CrossRef]

43. Fiqrianti, I.A.; Widiyanti, P.; Manaf, M.A.; Savira, C.Y.; Cahyani, N.R.; Bella, F.R. Poly-L-Lactic acid (PLLA)-chitosan-collagen electrospun tube for vascular graft application. J. Funct. Biomater. 2018, 9, 32. [CrossRef] [PubMed] 
44. Zhang, J.; Wang, D.; Jiang, X.; He, L.; Fu, L.; Zhao, Y.; Wang, Y.; Mo, H.; Shen, J. Multistructured vascular patches constructed via layer-by-layer self-assembly of heparin and chitosan for vascular tissue engineering applications. Chem. Eng. J. 2019, 370, 1057-1067. [CrossRef]

45. Rodrigues, M.N.; Oliveira, M.B.; Costa, R.R.; Mano, J.F. Chitosan/Chondroitin Sulfate Membranes Produced by Polyelectrolyte Complexation for Cartilage Engineering. Biomacromolecules 2016, 17, 2178-2188. [CrossRef] [PubMed]

46. Mirmusavi, M.H.; Zadehnajar, P.; Semnani, D.; Karbasi, S.; Fekrat, F.; Heidari, F. Evaluation of physical, mechanical and biological properties of poly 3-hydroxybutyrate-chitosan-multiwalled carbon nanotube/silk nano-micro composite scaffold for cartilage tissue engineering applications. Int. J. Biol. Macromol. 2019, 132, 822-835. [CrossRef]

47. Shamekhi, M.A.; Mirzadeh, H.; Mahdavi, H.; Rabiee, A.; Mohebbi-Kalhori, D.; Baghaban Eslaminejad, M. Graphene oxide containing chitosan scaffolds for cartilage tissue engineering. Int. J. Biol. Macromol. 2019, 127, 396-405. [CrossRef]

48. Cao, L.; Zhang, F.; Wang, Q.; Wu, X. Fabrication of chitosan/graphene oxide polymer nanofiber and its biocompatibility for cartilage tissue engineering. Mater. Sci. Eng. C 2017, 79, 697-701. [CrossRef]

49. Kar, S.; Kaur, T.; Thirugnanam, A. Microwave-assisted synthesis of porous chitosan-modified montmorillonite-hydroxyapatite composite scaffolds. Int. J. Biol. Macromol. 2016, 82, 628-636. [CrossRef]

50. Lei, Y.; Xu, Z.; Ke, Q.; Yin, W.; Chen, Y.; Zhang, C.; Guo, Y. Strontium hydroxyapatite/chitosan nanohybrid scaffolds with enhanced osteoinductivity for bone tissue engineering. Mater. Sci. Eng. C 2017, 72, 134-142. [CrossRef]

51. Ghorbani, M.; Ai, J.; Nourani, M.R.; Azami, M.; Hashemi Beni, B.; Asadpour, S.; Bordbar, S. Injectable natural polymer compound for tissue engineering of intervertebral disc: In vitro study. Mater. Sci. Eng. C 2017, 80, 502-508. [CrossRef]

52. Alinejad, Y.; Adoungotchodo, A.; Grant, M.P.; Epure, L.M.; Antoniou, J.; Mwale, F.; Lerouge, S. Injectable Chitosan Hydrogels with Enhanced Mechanical Properties for Nucleus Pulposus Regeneration. Tissue Eng.-Part A 2019, 25, 303-313. [CrossRef]

53. Yuan, D.; Chen, Z.; Xiang, X.; Deng, S.; Liu, K.; Xiao, D.; Deng, L.; Feng, G. The establishment and biological assessment of a whole tissue-engineered intervertebral disc with PBST fibers and a chitosan hydrogel in vitro and in vivo. J. Biomed. Mater. Res.-Part B Appl. Biomater. 2019, 107, 2305-2316. [CrossRef]

54. Trinca, R.B.; Westin, C.B.; da Silva, J.A.F.; Moraes, Â.M. Electrospun multilayer chitosan scaffolds as potential wound dressings for skin lesions. Eur. Polym. J. 2017, 88, 161-170. [CrossRef]

55. Madni, A.; Khan, R.; Ikram, M.; Naz, S.S.; Khan, T.; Wahid, F. Fabrication and characterization of chitosan-Vitamin C-lactic acid composite membrane for potential skin tissue engineering. Int. J. Polym. Sci. 2019, 2019. [CrossRef]

56. Luetchford, K.A.; Chaudhuri, J.B.; De Bank, P.A. Silk fibroin/gelatin microcarriers as scaffolds for bone tissue engineering. Mater. Sci. Eng. C 2020, 106. [CrossRef]

57. Gambari, L.; Amore, E.; Raggio, R.; Bonani, W.; Barone, M.; Lisignoli, G.; Grigolo, B.; Motta, A.; Grassi, F. Hydrogen sulfidereleasing silk fibroin scaffold for bone tissue engineering. Mater. Sci. Eng. C 2019, 102, 471-482. [CrossRef] [PubMed]

58. Bhardwaj, N.; Singh, Y.P.; Devi, D.; Kandimalla, R.; Kotoky, J.; Mandal, B.B. Potential of silk fibroin/chondrocyte constructs of muga silkworm Antheraea assamensis for cartilage tissue engineering. J. Mater. Chem. B 2016, 4, 3670-3684. [CrossRef] [PubMed]

59. Shi, W.; Sun, M.; Hu, X.; Ren, B.; Cheng, J.; Li, C.; Duan, X.; Fu, X.; Zhang, J.; Chen, H.; et al. Structurally and Functionally Optimized Silk-Fibroin-Gelatin Scaffold Using 3D Printing to Repair Cartilage Injury In Vitro and In Vivo. Adv. Mater. 2017, 29, 1-7. [CrossRef]

60. Singh, Y.P.; Bhardwaj, N.; Mandal, B.B. Potential of Agarose/Silk Fibroin Blended Hydrogel for in Vitro Cartilage Tissue Engineering. ACS Appl. Mater. Interfaces 2016, 8, 21236-21249. [CrossRef] [PubMed]

61. Allardyce, B.J.; Rajkhowa, R.; Dilley, R.J.; Xie, Z.; Campbell, L.; Keating, A.; Atlas, M.D.; von Unge, M.; Wang, X. Comparative acoustic performance and mechanical properties of silk membranes for the repair of chronic tympanic membrane perforations. $J$. Mech. Behav. Biomed. Mater. 2016, 64, 65-74. [CrossRef]

62. Su, T.; Zhang, M.; Zeng, Q.; Pan, W.; Huang, Y.; Qian, Y.; Dong, W.; Qi, X.; Shen, J. Mussel-inspired agarose hydrogel scaffolds for skin tissue engineering. Bioact. Mater. 2021, 6, 579-588. [CrossRef] [PubMed]

63. García-Martínez, L.; Campos, F.; Godoy-Guzmán, C.; del Carmen Sánchez-Quevedo, M.; Garzón, I.; Alaminos, M.; Campos, A.; Carriel, V. Encapsulation of human elastic cartilage-derived chondrocytes in nanostructured fibrin-agarose hydrogels. Histochem. Cell Biol. 2017, 147, 83-95. [CrossRef]

64. Bagheri, B.; Zarrintaj, P.; Surwase, S.S.; Baheiraei, N.; Saeb, M.R.; Mozafari, M.; Kim, Y.C.; Park, O.O. Self-gelling electroactive hydrogels based on chitosan-aniline oligomers/agarose for neural tissue engineering with on-demand drug release. Colloids Surf. B Biointerfaces 2019, 184. [CrossRef]

65. Carriel, V.; Garzón, I.; Campos, A.; Cornelissen, M.; Alaminos, M. Differential expression of GAP-43 and neurofilament during peripheral nerve regeneration through bio-artificial conduits. J. Tissue Eng. Regen. Med. 2017, 11, 553-563. [CrossRef]

66. Carriel, V.; Scionti, G.; Campos, F.; Roda, O.; Castro, B.; Cornelissen, M.; Garzón, I.; Alaminos, M. In vitro characterization of a nanostructured fibrin agarose bio-artificial nerve substitute. J. Tissue Eng. Regen. Med. 2017, 11, 1412-1426. [CrossRef]

67. Cavo, M.; Caria, M.; Pulsoni, I.; Beltrame, F.; Fato, M.; Scaglione, S. A new cell-laden 3D Alginate-Matrigel hydrogel resembles human breast cancer cell malignant morphology, spread and invasion capability observed "in vivo". Sci. Rep. 2018, 8, 1-12. [CrossRef] [PubMed]

68. Anguiano, M.; Castilla, C.; Maška, M.; Ederra, C.; Peláez, R.; Morales, X.; Muñoz-Arrieta, G.; Mujika, M.; Kozubek, M.; MuñozBarrutia, A.; et al. Characterization of three-dimensional cancer cell migration in mixed collagen-Matrigel scaffolds using microfluidics and image analysis. PLoS ONE 2017, 12, e0171417. [CrossRef] [PubMed] 
69. Si, J.; Lin, J.; Su, C.; Yu, S.; Cui, Z.; Wang, Q.; Chen, W.; Turng, L.S. Ultrasonication-Induced Modification of Hydroxyapatite Nanoparticles onto a 3D Porous Poly(lactic acid) Scaffold with Improved Mechanical Properties and Biocompatibility. Macromol. Mater. Eng. 2019, 304, 1900081. [CrossRef]

70. Zimina, A.; Senatov, F.; Choudhary, R.; Kolesnikov, E.; Anisimova, N.; Kiselevskiy, M.; Orlova, P.; Strukova, N.; Generalova, M.; Manskikh, V.; et al. Biocompatibility and physico-chemical properties of highly porous PLA/HA scaffolds for bone reconstruction. Polymers 2020, 12, 2938. [CrossRef] [PubMed]

71. Oladapo, B.I.; Daniyan, I.A.; Ikumapayi, O.M.; Malachi, O.B.; Malachi, I.O. Microanalysis of hybrid characterization of PLA/cHA polymer scaffolds for bone regeneration. Polym. Test. 2020, 83, 106341. [CrossRef]

72. Zhou, X.; Zhou, G.; Junka, R.; Chang, N.; Anwar, A.; Wang, H.; Yu, X. Fabrication of polylactic acid (PLA)-based porous scaffold through the combination of traditional bio-fabrication and 3D printing technology for bone regeneration. Colloids Surf. $B$ Biointerfaces 2021, 197. [CrossRef]

73. Zhang, B.; Wang, L.; Song, P.; Pei, X.; Sun, H.; Wu, L.; Zhou, C.; Wang, K.; Fan, Y.; Zhang, X. 3D printed bone tissue regenerative PLA/HA scaffolds with comprehensive performance optimizations. Mater. Des. 2021, 201, 109490. [CrossRef]

74. Eslami, H.; Azimi Lisar, H.; Jafarzadeh Kashi, T.S.; Tahriri, M.; Ansari, M.; Rafiei, T.; Bastami, F.; Shahin-Shamsabadi, A.; Mashhadi Abbas, F.; Tayebi, L. Poly (lactic-co-glycolic acid)(PLGA)/TiO2 nanotube bioactive composite as a novel scaffold for bone tissue engineering: In vitro and in vivo studies. Biologicals 2018, 53, 51-62. [CrossRef] [PubMed]

75. Babilotte, J.; Martin, B.; Guduric, V.; Bareille, R.; Agniel, R.; Roques, S.; Héroguez, V.; Dussauze, M.; Gaudon, M.; Le Nihouannen, D.; et al. Development and characterization of a PLGA-HA composite material to fabricate 3D-printed scaffolds for bone tissue engineering. Mater. Sci. Eng. C 2021, 118, 111334. [CrossRef]

76. Kim, H.J.; Han, M.A.; Shin, J.Y.; Jeon, J.H.; Lee, S.J.; Yoon, M.Y.; Kim, H.J.; Choi, E.J.; Do, S.H.; Yang, V.C.; et al. Intra-articular delivery of synovium-resident mesenchymal stem cells via BMP-7-loaded fibrous PLGA scaffolds for cartilage repair. J. Control. Release 2019, 302, 169-180. [CrossRef]

77. Wei, P.; Xu, Y.; Gu, Y.; Yao, Q.; Li, J.; Wang, L. IGF-1-releasing PLGA nanoparticles modified 3D printed PCL scaffolds for cartilage tissue engineering. Drug Deliv. 2020, 27, 1106-1114. [CrossRef] [PubMed]

78. Moradian, H.; Keshvari, H.; Fasehee, H.; Dinarvand, R.; Faghihi, S. Combining NT3-overexpressing MSCs and PLGA microcarriers for brain tissue engineering: A potential tool for treatment of Parkinson's disease. Mater. Sci. Eng. C 2017, 76, 934-943. [CrossRef]

79. Zhou, L.; Tu, J.; Fang, G.; Deng, L.; Gao, X.; Guo, K.; Kong, J.; Lv, J.; Guan, W.; Yang, C. Combining PLGA scaffold and MSCs for brain tissue engineering: A potential tool for treatment of brain injury. Stem Cells Int. 2018, 2018. [CrossRef] [PubMed]

80. Gelse, K.; Pöschl, E.; Aigner, T. Collagens-Structure, function, and biosynthesis. Adv. Drug Deliv. Rev. 2003, 55, 1531-1546. [CrossRef] [PubMed]

81. Pawelec, K.M.; Best, S.M.; Cameron, R.E. Collagen: A network for regenerative medicine. J. Mater. Chem. B 2016, 4, 6484-6496. [CrossRef] [PubMed]

82. Maller, O.; Drain, A.P.; Barrett, A.S.; Borgquist, S.; Ruffell, B.; Zakharevich, I.; Pham, T.T.; Gruosso, T.; Kuasne, H.; Lakins, J.N.; et al. Tumour-associated macrophages drive stromal cell-dependent collagen crosslinking and stiffening to promote breast cancer aggression. Nat. Mater. 2021, 20, 548-559. [CrossRef] [PubMed]

83. Barcellos-de-Souza, P.; Gori, V.; Bambi, F.; Chiarugi, P. Tumor microenvironment: Bone marrow-mesenchymal stem cells as key players. Biochim. Biophys. Acta-Rev. Cancer 2013, 1836, 321-335. [CrossRef]

84. Law, J.X.; Liau, L.L.; Saim, A.; Yang, Y.; Idrus, R. Electrospun Collagen Nanofibers and Their Applications in Skin Tissue Engineering. Tissue Eng. Regen. Med. 2017, 14, 699-718. [CrossRef]

85. Mizuno, M.; Fujisawa, R.; Kuboki, Y. Type I collagen-induced osteoblastic differentiation of bone-marrow cells mediated by collagen- $\alpha 2 \beta 1$ integrin interaction. J. Cell. Physiol. 2000, 184, 207-213. [CrossRef]

86. Irawan, V.; Sung, T.C.; Higuchi, A.; Ikoma, T. Collagen Scaffolds in Cartilage Tissue Engineering and Relevant Approaches for Future Development. Tissue Eng. Regen. Med. 2018, 15, 673-697. [CrossRef]

87. Copes, F.; Pien, N.; Van Vlierberghe, S.; Boccafoschi, F.; Mantovani, D. Collagen-based tissue engineering strategies for vascular medicine. Front. Bioeng. Biotechnol. 2019, 7, 1-15. [CrossRef] [PubMed]

88. Nguyen-Ngoc, K.V.; Cheung, K.J.; Brenot, A.; Shamir, E.R.; Gray, R.S.; Hines, W.C.; Yaswen, P.; Werb, Z.; Ewald, A.J. ECM microenvironment regulates collective migration and local dissemination in normal and malignant mammary epithelium. Proc. Natl. Acad. Sci. USA 2012, 109, 19-24. [CrossRef] [PubMed]

89. Kuczek, D.E.; Larsen, A.M.H.; Carretta, M.; Kalvisa, A.; Siersbæk, M.S.; Simões, A.M.C.; Roslind, A.; Engelholm, L.H.; Donia, M.; Svane, I.M.; et al. Collagen density regulates the activity of tumor-infiltrating T cells. J. Immunother. Cancer 2018, 6, 1-15. [CrossRef]

90. Tabata, Y.; Ikada, Y. Protein release from gelatin matrices. Adv. Drug Deliv. Rev. 1998, 31, 287-301. [CrossRef]

91. Nii, T.; Makino, K.; Tabata, Y. Influence of shaking culture on the biological functions of cell aggregates incorporating gelatin hydrogel microspheres. J. Biosci. Bioeng. 2019, 128, 606-612. [CrossRef]

92. Hayashi, K.; Tabata, Y. Preparation of stem cell aggregates with gelatin microspheres to enhance biological functions. Acta Biomater. 2011, 7, 2797-2803. [CrossRef]

93. Kellner, K.; Liebsch, G.; Klimant, I.; Wolfbeis, O.S.; Blunk, T.; Schulz, M.B.; Göpferich, A. Determination of oxygen gradients in engineered tissue using a fluorescent sensor. Biotechnol. Bioeng. 2002, 80, 73-83. [CrossRef] [PubMed] 
94. Kawai, K.; Suzuki, S.; Tabata, Y.; Ikada, Y.; Nishimura, Y. Accelerated tissue regeneration through incorporation of basic fibroblast growth factor-impregnated gelatin microspheres into artificial dermis. Biomaterials 2000, 21, 489-499. [CrossRef]

95. Tabata, Y.; Ikada, Y. Vascularization effect of basic fibroblast growth factor released from gelatin hydrogels with different biodegradabilities. Biomaterials 1999, 20, 2169-2175. [CrossRef]

96. Siegel, R.L.; Miller, K.D.; Jemal, A. Cancer statistics, 2019. CA: Cancer J. Clin. 2019, 69, 7-34. [CrossRef] [PubMed]

97. Shiga, K.; Hara, M.; Nagasaki, T.; Sato, T.; Takahashi, H.; Takeyama, H. Cancer-associated fibroblasts: Their characteristics and their roles in tumor growth. Cancers 2015, 7, 2443-2458. [CrossRef]

98. Matsuno, K.; Saotome, T.; Shimada, N.; Nakamura, K.; Tabata, Y. Effect of cell seeding methods on the distribution of cells into the gelatin hydrogel nonwoven fabric. Regen. Ther. 2020, 14, 160-164. [CrossRef]

99. Nakamura, K.; Saotome, T.; Shimada, N.; Matsuno, K.; Tabata, Y. A Gelatin Hydrogel Nonwoven Fabric Facilitates Metabolic Activity of Multilayered Cell Sheets. Tissue Eng.-Part C Methods 2019, 25, 344-352. [CrossRef]

100. Nakamura, K.; Nobutani, K.; Shimada, N.; Tabata, Y. Gelatin hydrogel-fragmented fibers suppress shrinkage of cell sheet. Tissue Eng.-Part C Methods 2020, 26, 216-224. [CrossRef]

101. Murata, Y.; Jo, J.I.; Tabata, Y. Intracellular controlled release of molecular beacon prolongs the time period of mRNA visualization. Tissue Eng.-Part A 2019, 25, 1527-1537. [CrossRef] [PubMed]

102. Murata, Y.; Jo, J.I.; Tabata, Y. Visualization of Apoptosis in Three-Dimensional Cell Aggregates Based on Molecular Beacon Imaging. Tissue Eng.-Part C Methods 2021, 27, 264-275. [CrossRef]

103. Yoshimoto, Y.; Jo, J.I.; Tabata, Y. Preparation of antibody-immobilized gelatin nanospheres incorporating a molecular beacon to visualize the biological function of macrophages. Regen. Ther. 2020, 14, 11-18. [CrossRef]

104. Murata, Y.; Jo, J.-I.; Tabata, Y. Molecular Beacon Imaging to Visualize Ki67 mRNA for Cell Proliferation Ability. Tissue Eng. Part A 2021, 27, 526-535. [CrossRef] [PubMed]

105. Agüero, L.; Zaldivar-Silva, D.; Peña, L.; Dias, M. Alginate microparticles as oral colon drug delivery device: A review. Carbohydr. Polym. 2017, 168, 32-43. [CrossRef] [PubMed]

106. Scott, J.E. Supramolecular organization of extracellular matrix glycosaminoglycans, in vitro and in the tissues. FASEB J. 1992, 6 , 2639-2645. [CrossRef] [PubMed]

107. Lopez-Sanchez, P.; Fredriksson, N.; Larsson, A.; Altskär, A.; Ström, A. High sugar content impacts microstructure, mechanics and release of calcium-alginate gels. Food Hydrocoll. 2018, 84, 26-33. [CrossRef]

108. Hu, C.; Lu, W.; Mata, A.; Nishinari, K.; Fang, Y. Ions-induced gelation of alginate: Mechanisms and applications. Int. J. Biol. Macromol. 2021, 177, 578-588. [CrossRef]

109. Kanafi, M.M.; Ramesh, A.; Gupta, P.K.; Bhonde, R.R. Dental pulp stem cells immobilized in alginate microspheres for applications in bone tissue engineering. Int. Endod. J. 2014, 47, 687-697. [CrossRef]

110. Utech, S.; Prodanovic, R.; Mao, A.S.; Ostafe, R.; Mooney, D.J.; Weitz, D.A. Microfluidic Generation of Monodisperse, Structurally Homogeneous Alginate Microgels for Cell Encapsulation and 3D Cell Culture. Adv. Healthc. Mater. 2015, 4, 1628-1633. [CrossRef] [PubMed]

111. Meier, R.P.H.; Mahou, R.; Morel, P.; Meyer, J.; Montanari, E.; Muller, Y.D.; Christofilopoulos, P.; Wandrey, C.; Gonelle-Gispert, C.; Bühler, L.H. Microencapsulated human mesenchymal stem cells decrease liver fibrosis in mice. J. Hepatol. 2015, 62, 634-641. [CrossRef]

112. Qi, M.; Mørch, Y.; Lacík, I.; Formo, K.; Marchese, E.; Wang, Y.; Danielson, K.K.; Kinzer, K.; Wang, S.; Barbaro, B.; et al. Survival of human islets in microbeads containing high guluronic acid alginate crosslinked with $\mathrm{Ca}^{2+}$ and $\mathrm{Ba}^{2+}$. Xenotransplantation 2012, 19, 355-364. [CrossRef] [PubMed]

113. Mujtaba, M.; Morsi, R.E.; Kerch, G.; Elsabee, M.Z.; Kaya, M.; Labidi, J.; Khawar, K.M. Current advancements in chitosan-based film production for food technology; A review. Int. J. Biol. Macromol. 2019, 121, 889-904. [CrossRef] [PubMed]

114. Gu, Z.; Xie, H.X.; Huang, C.; Li, L.; Yu, X. Preparation of chitosan/silk fibroin blending membrane fixed with alginate dialdehyde for wound dressing. Int. J. Biol. Macromol. 2013, 58, 121-126. [CrossRef]

115. Bakshi, P.S.; Selvakumar, D.; Kadirvelu, K.; Kumar, N.S. Comparative study on antimicrobial activity and biocompatibility of N-selective chitosan derivatives. React. Funct. Polym. 2018, 124, 149-155. [CrossRef]

116. Kumar, R.; Oves, M.; Ameelbi, T.; Al-Makishah, N.H.; Barakat, M.A. Hybrid chitosan/polyaniline-polypyrrole biomaterial for enhanced adsorption and antimicrobial activity. J. Colloid Interface Sci. 2017, 490, 488-496. [CrossRef]

117. Wang, H.; Qian, J.; Ding, F. Emerging Chitosan-Based Films for Food Packaging Applications. J. Agric. Food Chem. 2018, 66, 395-413. [CrossRef]

118. Duan, C.; Meng, X.; Meng, J.; Khan, M.I.H.; Dai, L.; Khan, A.; An, X.; Zhang, J.; Huq, T.; Ni, Y. Chitosan as A Preservative for Fruits and Vegetables: A Review on Chemistry and Antimicrobial Properties. J. Bioresour. Bioprod. 2019, 4, 11-21. [CrossRef]

119. Rocha, M.A.M.; Coimbra, M.A.; Nunes, C. Applications of chitosan and their derivatives in beverages: A critical review. Curr. Opin. Food Sci. 2017, 15, 61-69. [CrossRef]

120. Baldrick, P. The safety of chitosan as a pharmaceutical excipient. Regul. Toxicol. Pharmacol. 2010, 56, 290-299. [CrossRef] [PubMed]

121. Tzaneva, D.; Simitchiev, A.; Petkova, N.; Nenov, V.; Stoyanova, A.; Denev, P. Synthesis of carboxymethyl chitosan and its rheological behaviour in pharmaceutical and cosmetic emulsions. J. Appl. Pharm. Sci. 2017, 7, 70-78. [CrossRef]

122. Neves, S.C.; Moreira Teixeira, L.S.; Moroni, L.; Reis, R.L.; Van Blitterswijk, C.A.; Alves, N.M.; Karperien, M.; Mano, J.F. Chitosan/Poly ( $\varepsilon$-caprolactone) blend scaffolds for cartilage repair. Biomaterials 2011, 32, 1068-1079. [CrossRef] 
123. Kashi, M.; Baghbani, F.; Moztarzadeh, F.; Mobasheri, H.; Kowsari, E. Green synthesis of degradable conductive thermosensitive oligopyrrole/chitosan hydrogel intended for cartilage tissue engineering. Int. J. Biol. Macromol. 2018, 107, 1567-1575. [CrossRef]

124. Aranaz, I.; Martínez-Campos, E.; Moreno-Vicente, C.; Civantos, A.; García-Arguelles, S.; del Monte, F. Macroporous calcium phosphate/chitosan composites prepared via unidirectional ice segregation and subsequent freeze-drying. Materials 2017, 10, 516. [CrossRef]

125. Balagangadharan, K.; Dhivya, S.; Selvamurugan, N. Chitosan based nanofibers in bone tissue engineering. Int. J. Biol. Macromol. 2017, 104, 1372-1382. [CrossRef]

126. Logithkumar, R.; Keshavnarayan, A.; Dhivya, S.; Chawla, A.; Saravanan, S.; Selvamurugan, N. A review of chitosan and its derivatives in bone tissue engineering. Carbohydr. Polym. 2016, 151, 172-188. [CrossRef] [PubMed]

127. Doench, I.; Torres-Ramos, M.E.W.; Montembault, A.; de Oliveira, P.N.; Halimi, C.; Viguier, E.; Heux, L.; Siadous, R.; Thiré, R.M.S.M.; Osorio-Madrazo, A. Injectable and gellable chitosan formulations filled with cellulose nanofibers for intervertebral disc tissue engineering. Polymers 2018, 10, 1202. [CrossRef] [PubMed]

128. Doench, I.; Tran, T.; David, L.; Montembault, A.; Viguier, E.; Gorzelanny, C.; Sudre, G.; Cachon, T.; Louback-Mohamed, M.; Horbelt, N.; et al. Cellulose Nanofiber-Reinforced Chitosan Hydrogel Composites for Intervertebral Disc Tissue Repair. Biomimetics 2019, 4, 19. [CrossRef]

129. Tchemtchoua, V.T.; Atanasova, G.; Aqil, A.; Filée, P.; Garbacki, N.; Vanhooteghem, O.; Deroanne, C.; Noël, A.; Jérome, C.; Nusgens, B.; et al. Development of a Chitosan Nanofibrillar Scaffold for Skin Repair and Regeneration. Biomacromolecules 2011, 12, 3194-3204. [CrossRef] [PubMed]

130. Keong, L.C.; Halim, A.S. In Vitro models in biocompatibility assessment for biomedical-grade chitosan derivatives in wound management. Int. J. Mol. Sci. 2009, 10, 1300-1313. [CrossRef]

131. Liu, B.; Song, Y.W.; Jin, L.; Wang, Z.J.; Pu, D.Y.; Lin, S.Q.; Zhou, C.; You, H.J.; Ma, Y.; Li, J.M.; et al. Silk structure and degradation. Colloids Surf. B Biointerfaces 2015, 131, 122-128. [CrossRef]

132. Malay, A.D.; Sato, R.; Yazawa, K.; Watanabe, H.; Ifuku, N.; Masunaga, H.; Hikima, T.; Guan, J.; Mandal, B.B.; Damrongsakkul, S.; et al. Relationships between physical properties and sequence in silkworm silks. Sci. Rep. 2016, 6, 1-11. [CrossRef] [PubMed]

133. Vepari, C.; Kaplan, D.L. Silk as a biomaterial. Prog. Polym. Sci. 2007, 32, 991-1007. [CrossRef] [PubMed]

134. Nguyen, T.P.; Nguyen, Q.V.; Nguyen, V.-H.; Le, T.-H.; Huynh, V.Q.N.; Vo, D.-V.N.; Trinh, Q.T.; Kim, S.Y.; Le, Q.V. Silk Fibroin-Based Biomaterials for Biomedical Applications: A Review. Polymers 2019, 11, 1933. [CrossRef] [PubMed]

135. Jiao, Z.; Song, Y.; Jin, Y.; Zhang, C.; Peng, D.; Chen, Z.; Chang, P.; Kundu, S.C.; Wang, G.; Wang, Z.; et al. In Vivo Characterizations of the Immune Properties of Sericin: An Ancient Material with Emerging Value in Biomedical Applications. Macromol. Biosci. 2017, 17, 1-6. [CrossRef]

136. Panilaitis, B.; Altman, G.H.; Chen, J.; Jin, H.J.; Karageorgiou, V.; Kaplan, D.L. Macrophage responses to silk. Biomaterials 2003, 24, 3079-3085. [CrossRef]

137. Sahu, N.; Pal, S.; Sapru, S.; Kundu, J.; Talukdar, S.; Singh, N.I.; Yao, J.; Kundu, S.C. Non-Mulberry and Mulberry Silk Protein Sericins as Potential Media Supplement for Animal Cell Culture. BioMed Res. Int. 2016, 2016. [CrossRef] [PubMed]

138. Tomeh, M.A.; Hadianamrei, R.; Zhao, X. Silk fibroin as a functional biomaterial for drug and gene delivery. Pharmaceutics 2019, 11, 494. [CrossRef] [PubMed]

139. Cao, Y.; Wang, B. Biodegradation of silk biomaterials. Int. J. Mol. Sci. 2009, 10, 1514-1524. [CrossRef]

140. Meinel, L.; Hofmann, S.; Betz, O.; Fajardo, R.; Merkle, H.P.; Langer, R.; Evans, C.H.; Vunjak-Novakovic, G.; Kaplan, D.L. Osteogenesis by human mesenchymal stem cells cultured on silk biomaterials: Comparison of adenovirus mediated gene transfer and protein delivery of BMP-2. Biomaterials 2006, 27, 4993-5002. [CrossRef]

141. Uebersax, L.; Merkle, H.P.; Meinel, L. Insulin-like growth factor I releasing silk fibroin scaffolds induce chondrogenic differentiation of human mesenchymal stem cells. J. Control. Release 2008, 127, 12-21. [CrossRef]

142. Liu, H.; Fan, H.; Wang, Y.; Toh, S.L.; Goh, J.C.H. The interaction between a combined knitted silk scaffold and microporous silk sponge with human mesenchymal stem cells for ligament tissue engineering. Biomaterials 2008, 29, 662-674. [CrossRef]

143. Zhang, W.; Chen, L.; Chen, J.; Wang, L.; Gui, X.; Ran, J.; Xu, G.; Zhao, H.; Zeng, M.; Ji, J.; et al. Silk Fibroin Biomaterial Shows Safe and Effective Wound Healing in Animal Models and a Randomized Controlled Clinical Trial. Adv. Healthc. Mater. 2017, 6, 1-16. [CrossRef]

144. Farokhi, M.; Mottaghitalab, F.; Fatahi, Y.; Khademhosseini, A.; Kaplan, D.L. Overview of Silk Fibroin Use in Wound Dressings. Trends Biotechnol. 2018, 36, 907-922. [CrossRef]

145. Zhang, W.; Wang, X.; Wang, S.; Zhao, J.; Xu, L.; Zhu, C.; Zeng, D.; Chen, J.; Zhang, Z.; Kaplan, D.L.; et al. The use of injectable sonication-induced silk hydrogel for VEGF 165 and BMP-2 delivery for elevation of the maxillary sinus floor. Biomaterials 2011, 32, 9415-9424. [CrossRef]

146. Zarrintaj, P.; Manouchehri, S.; Ahmadi, Z.; Saeb, M.R.; Urbanska, A.M.; Kaplan, D.L.; Mozafari, M. Agarose-based biomaterials for tissue engineering. Carbohydr. Polym. 2018, 187, 66-84. [CrossRef]

147. Zarrintaj, P.; Bakhshandeh, B.; Rezaeian, I.; Heshmatian, B.; Ganjali, M.R. A Novel Electroactive Agarose-Aniline Pentamer Platform as a Potential Candidate for Neural Tissue Engineering. Sci. Rep. 2017, 7, 1-12. [CrossRef] [PubMed]

148. Kim, C.; Jeong, D.; Kim, S.; Kim, Y.; Jung, S. Cyclodextrin functionalized agarose gel with low gelling temperature for controlled drug delivery systems. Carbohydr. Polym. 2019, 222, 115011. [CrossRef] [PubMed] 
149. Rahfoth, B.; Weisser, J.; Sternkopf, F.; Aigner, T.; Von Der Mark, K.; Bräuer, R. Transplantation of allograft chondrocytes embedded in agarose gel into cartilage defects of rabbits. Osteoarthr. Cartil. 1998, 6, 50-65. [CrossRef]

150. Ionescu, A.M.; Cardona, J.; Ghinea, R.; Garzón Bello, I.; González-Andrades, M.; Alaminos, M.; Pérez, M.; del Mar Pérez, M. Optical properties of an anterior lamellar human cornea model based on fibrin-agarose. In Third International Conference on Applications of Optics and Photonics; International Society for Optics and Photonics: Bellingham, WA, USA, 2017; Volume 10453, p. 104532J. [CrossRef]

151. Miller, R.T. Mechanical properties of basement membrane in health and disease. Matrix Biol. 2017, 57-58, 366-373. [CrossRef] [PubMed]

152. Glentis, A.; Oertle, P.; Mariani, P.; Chikina, A.; El Marjou, F.; Attieh, Y.; Zaccarini, F.; Lae, M.; Loew, D.; Dingli, F.; et al. Cancerassociated fibroblasts induce metalloprotease-independent cancer cell invasion of the basement membrane. Nat. Commun. 2017, 8, 1-13. [CrossRef]

153. Chang, J.; Chaudhuri, O. Beyond proteases: Basement membrane mechanics and cancer invasion. J. Cell Biol. 2019, 218, 2456-2469. [CrossRef] [PubMed]

154. Aisenbrey, E.A.; Murphy, W.L. Synthetic alternatives to Matrigel. Nat. Rev. Mater. 2020, 5, 539-551. [CrossRef] [PubMed]

155. Serratì, S.; Porcelli, L.; Guida, S.; Ferretta, A.; Iacobazzi, R.M.; Cocco, T.; Maida, I.; Tamasi, G.; Rossi, C.; Manganelli, M.; et al. Tomatine displays antitumor potential in in vitro models of metastatic melanoma. Int. J. Mol. Sci. 2020, 21, 5243. [CrossRef]

156. Kenny, P.A.; Lee, G.Y.; Myers, C.A.; Neve, R.M.; Semeiks, J.R.; Spellman, P.T.; Lorenz, K.; Lee, E.H.; Barcellos-Hoff, M.H.; Petersen, O.W.; et al. The morphologies of breast cancer cell lines in three-dimensional assays correlate with their profiles of gene expression. Mol. Oncol. 2007, 1, 84-96. [CrossRef]

157. Buzarovska, A.; Dinescu, S.; Chitoiu, L.; Costache, M. Porous poly(l-lactic acid) nanocomposite scaffolds with functionalized TiO2 nanoparticles: Properties, cytocompatibility and drug release capability. J. Mater. Sci. 2018, 53, 11151-11166. [CrossRef]

158. Grémare, A.; Guduric, V.; Bareille, R.; Heroguez, V.; Latour, S.; L'heureux, N.; Fricain, J.C.; Catros, S.; Le Nihouannen, D. Characterization of printed PLA scaffolds for bone tissue engineering. J. Biomed. Mater. Res.-Part A 2018, 106, 887-894. [CrossRef]

159. Chen, J.; Yu, M.; Guo, B.; Ma, P.X.; Yin, Z. Conductive nanofibrous composite scaffolds based on in-situ formed polyaniline nanoparticle and polylactide for bone regeneration. J. Colloid Interface Sci. 2018, 514, 517-527. [CrossRef]

160. Farah, S.; Anderson, D.G.; Langer, R. Physical and mechanical properties of PLA, and their functions in widespread applicationsA comprehensive review. Adv. Drug Deliv. Rev. 2016, 107, 367-392. [CrossRef]

161. Liu, S.; Qin, S.; He, M.; Zhou, D.; Qin, Q.; Wang, H. Current applications of poly (lactic acid) composites in tissue engineering and drug delivery. Compos. Part B Eng. 2020, 199, 108238. [CrossRef]

162. Skidmore, S.; Hadar, J.; Garner, J.; Park, H.; Park, K.; Wang, Y.; Jiang, X. (Jeff) Complex sameness: Separation of mixed poly (lactide-co-glycolide) s based on the lactide:glycolide ratio. J. Control. Release 2019, 300, 174-184. [CrossRef]

163. Nii, T.; Takeuchi, I.; Kimura, Y.; Makino, K. Effects of the conformation of PLGA molecules in the organic solvent on the aerodynamic diameter of spray dried microparticles. Colloids Surf. A Physicochem. Eng. Asp. 2018, 539, 347-353. [CrossRef]

164. Enayati, M.; Mobedi, H.; Hojjati-Emami, S.; Mirzadeh, H.; Jafari-Nodoushan, M. In situ forming PLGA implant for 90 days controlled release of leuprolide acetate for treatment of prostate cancer. Polym. Adv. Technol. 2017, 28, 867-875. [CrossRef]

165. Sulong, A.F.; Fiassan, N.H.; Hwei, N.M.; Lokanathan, Y.; Naicker, A.S.; Abdullah, S.; Yusof, M.R.; Htwe, O.; Idrus, R.B.H.; Haflah, N.H.M. Collagen-Coated Polylactic-Glycolic Acid (PLGA) seeded with neural-differentiated human mesenchymal stem cells as a potential nerve conduit. Adv. Clin. Exp. Med. 2014, 23, 353-362. [CrossRef] [PubMed]

166. Hadlock, T.; Sundback, C.; Hunter, D.; Cheney, M.; Vacanti, J.P. A polymer foam conduit seeded with Schwann cells promotes guided peripheral nerve regeneration. Tissue Eng. 2000, 6, 119-127. [CrossRef] [PubMed]

167. Liu, H.; Lv, P.; Zhu, Y.; Wu, H.; Zhang, K.; Xu, F.; Zheng, L.; Zhao, J. Salidroside promotes peripheral nerve regeneration based on tissue engineering strategy using Schwann cells and PLGA: In vitro and in vivo. Sci. Rep. 2017, 7, 1-11. [CrossRef]

168. Momotori, N.; Jo, J.i.; Tabata, Y. Preparation of polymer microspheres capable for pioglitazone release to modify macrophages function. Regen. Ther. 2019, 11, 131-138. [CrossRef] [PubMed]

169. Fadeel, B. Hide and seek: Nanomaterial interactions with the immune system. Front. Immunol. 2019, 10, 1-10. [CrossRef] [PubMed]

170. Keshavan, S.; Calligari, P.; Stella, L.; Fusco, L.; Delogu, L.G.; Fadeel, B. Nano-bio interactions: A neutrophil-centric view. Cell Death Dis. 2019, 10, 1-11. [CrossRef] 